Short title: Using wastes to reduce greenhouse-gas emissions

\title{
INDUSTRIAL AND AGRICULTURAL WASTES DECREASED GREENHOUSE-GAS EMISSIONS AND INCREASED RICE GRAIN YIELD IN A SUBTROPICAL PADDY FIELD
}

By WEIQI WANG ${ }^{1,2^{*}}$, CONGSHENG ZENG ${ }^{1,2}$, JORDI SARDANS ${ }^{3,4^{*}}$, DONGPING ZENG $^{1,2}$, CHUN WANG $^{1,2}$, MIREIA BARTRONS ${ }^{3,4}$, JOSEP PENUELAS $^{3,4}$

${ }^{1}$ Institute of Geography, Fujian Normal University, Fuzhou 350007, China; ${ }^{2}$ Key Laboratory of Humid Subtropical Eco-geographical Process, Ministry of Education, Fujian Normal University, Fuzhou 350007, China ${ }^{3}$ CSIC, Global Ecology Unit CREAF- CSIC-UAB, Bellaterra, 08193 Barcelona, Catalonia, Spain; 4 CREAF, Cerdanyola del Valles, 08193 Barcelona, Catalonia, Spain,; Aquatic Ecology Group, BETA Tecnio Centre, University of Vic - Central University of Catalonia, Vic, Catalonia, Spain;*Corresponding authors: Email: wangweiqi15@163.com; j.sardans@creaf.uab.cat

\section{SUMMARY}

Reducing the emissions of greenhouse gases (GHG) from paddy fields is crucial both for the sustainability of rice production and mitigation of global climatic warming. The effects of applying industrial and agricultural wastes as fertilizer on the reduction of GHG emissions in cropland areas, however, remain poorly known. We studied the effects of the application of $8 \mathrm{Mg} \mathrm{ha}^{-1}$ of diverse wastes on GHG emission and rice yield in a subtropical paddy in southeastern China. Plots fertilized with steel slag, biochar, shell slag, gypsum slag and silicate and calcium fertilizer had lower total global-warming potentials (GWP, including $\mathrm{CO}_{2}, \mathrm{CH}_{4}$ and $\mathrm{N}_{2} \mathrm{O}$ emissions) per unit area than control plots without waste application despite no significant differences among these treatments. Structural equation models showed that the effects of these fertilization treatments on gas emissions were partially due to their effects on soil variables, such as soil water content or soil salinity. Steel slag, biochar and shell slag increased rice yield by $7.1,15.5$ and $6.5 \%$, respectively. The biochar amendment had a $40 \%$ lower GWP by $\mathrm{Mg}^{-1}$ yield production, relative to the control. These results thus encourage further studies of the suitability of the use waste materials as fertilizers in other different types of paddy field as a way to mitigate GHG emissions and increase crop yield.

Keywords: $\mathrm{CH}_{4}$ flux; climate change; $\mathrm{CO}_{2}$ flux; crop yield; biochar; gypsum slag; $\mathrm{N}_{2} \mathrm{O}$ flux; paddy field; pollution; shell slag; silicate and calcium fertilizer; steel slag

1 Post-print of: Wang, W. et al. "Industrial and agricultural wastes decreased greenhouse-gas emissions and increased rice grain yield in a subtropical paddy field" in Experimental agriculture (Cambridge Univ. Press). Published online 13 july 2017 . The final versión is available at DOI 10.1017/ S001447971700031X 


\section{INTRODUCTION}

As rice is currently the basic food source of more than $50 \%$ of the global population, rice production will need to increase by $40 \%$ by the end of 2030 to meet the demand for food from the growing population worldwide (FAO, 2009). On the other hand, agricultural activities contribute to approximately one-fifth of the present emissions of atmospheric greenhouse gases (GHGs) (Hütsch, 2001). The emissions of methane $\left(\mathrm{CH}_{4}\right)$ and nitrous oxide $\left(\mathrm{N}_{2} \mathrm{O}\right)$ from paddy fields are especially relevant (Hütsch, 2001). So minimizing the GHGs from paddies is of utmost importance to mitigate their adverse impacts on climate change. The application of materials such as biochar (Zhang et al., 2010) or steel slag (Wang et al., 2015) is widely studied for both increasing rice yields and mitigating GHG emissions. Industrial and agricultural wastes contain high concentrations of electron acceptors such as the active and free oxide forms of iron, sulphur, nitrogen and phosphorus.

Steel slag and biochar are particularly commonly used in crop amendment in several areas of the world (Revell et al., 2012; Wang et al., 2015). Ali et al. (2008) observed that steel slag application reduced $\mathrm{CH}_{4}$ emissions in a temperate paddy field. Biochar is also a commonly used waste product (Revell et al., 2012) and its use can reduce $\mathrm{N}_{2} \mathrm{O}$ emissions from paddies (Zhang et al., 2010). However, biochar effectiveness in mitigating $\mathrm{CH}_{4}$ emissions has not been ever observed and depends on the type of biochar (Feng et al., 2012). The effects of slag and biochar on the reduction of $\mathrm{CO}_{2}$ emissions have been less studied compared to the emissions of $\mathrm{CH}_{4}$ and $\mathrm{N}_{2} \mathrm{O}$ from paddies. Few studies have provided an overall evaluation of the total globalwarming potential (GWP) from the combined emission contributions of the three main GWPs that are $\mathrm{CO}_{2}, \mathrm{CH}_{4}$ and $\mathrm{N}_{2} \mathrm{O}$ (Wang et al., 2015). Waste of the steel slag and silicate and calcium slag are rich in $\mathrm{Fe}$. Fe is one of the controlling factors affecting the $\mathrm{CO}_{2}, \mathrm{CH}_{4}$ and $\mathrm{N}_{2} \mathrm{O}$ production and emission (Huang et al., 2012; Wang et al., 2015). The application of waste rich in Fe will increase the amount of iron plaque on the rice roots limiting the transport of materials between rice roots and soil (Huang et al., 2012), and thus limiting the gas release from roots to the atmosphere. Moreover, when soil $\mathrm{Fe}^{3+}$ concentrations increase, the rate of $\mathrm{Fe}^{3+}$ reduction can also increase, thus also increasing $\mathrm{Fe}^{2+}$ accumulation in soil (Wang et al., 2015), which could inhibit microbial activity (Huang et al., 2009) and thus affect soil $\mathrm{CO}_{2}$ and $\mathrm{CH}_{4}$ production and emission. However, the effect of $\mathrm{Fe}$ on the $\mathrm{N}_{2} \mathrm{O}$ production and emission is more complex (Huang et al., 2009; Wang et al., 2015). Industrial and agricultural wastes are far less commonly applied in subtropical compared to temperate paddy fields (Ali et al., 2008; Wang et al., 2015), and less information is available on their impacts in GHG emissions and yield in subtropical paddy fields.

China has the second largest area of rice cultivation in the world, and GHG emissions from rice cultivation account for about $40 \%$ of the total agricultural source of GHGs. Ninety percent of the paddies in China are in the subtropics, such as in Fujian, Jiangxi and Hunan Provinces. Developing effective strategies to increase crop yield and mitigate GHG emissions from paddies in subtropical China to minimize future 
problems of food shortage and adverse climate change is thus of national and global importance.

Previous studies reported that steel slag was an effective amendment to reduce $\mathrm{CH}_{4}$ flux and increase rice yields in a subtropical paddy in Fujian Province in China over growing season (Wang et al., 2015). The effect on $\mathrm{N}_{2} \mathrm{O}$ emissions, however, was uncertain during the growth period of the rice crop (Wang et al., 2015). A silicate and calcium fertilizer produced from steel slag can be also useful as a chemical fertilizer that does not decrease water retention (Pernes-Debuyser and Tessier, 2004). Industrial and agricultural wastes represent an inexpensive and highly available potential source of fertilizer that can be useful tools to increase rice yield and mitigate GHG emissions. Shell slag from coastal fishing is easily obtained in large amounts in several areas of China and can be used in coastal rice croplands, and thus we have included this compound as fertilizer for the first time in rice crops. Gypsum slag is also produced in large amounts as waste from building activities due to the rapid growth of cities in China and is thus a good candidate to be used in rice croplands near cities. To reuse waste in the local region is very important to solve two problems at once: reduce residual accumulation and improve paddy field management.

Our objective was thus to obtain information for the use of waste materials to mitigate GHG emissions and increase rice yield by studying the effects of the application of various waste materials (steel slag, shell slag, biochar, gypsum slag and a silicate and calcium fertilizer produced from steel slag) under field conditions. We pursued this objective by: (1) determining the response of $\mathrm{CO}_{2}, \mathrm{CH}_{4}$ and $\mathrm{N}_{2} \mathrm{O}$ emissions to the application of different types of industrial and agricultural waste in a paddy, (2) analysing the soil variables changed by industrial and agricultural wastes that thereafter were related with $\mathrm{CO}_{2}, \mathrm{CH}_{4}$ and $\mathrm{N}_{2} \mathrm{O}$ emissions changes, and (3) assessing the impacts of the applications on crop productivity.

\section{MATERIALS AND METHODS}

\section{Study site and experimental design}

We studied the effect of the application of $8 \mathrm{Mg} \mathrm{ha}^{-1}$ of steel slag, biochar, shell slag, gypsum slag and a silicate and calcium fertilizer (produced from steel slag) on GHG emissions and on rice yield in a subtropical paddy field in southeastern China. The management (including soil plow, water management, fertilizer dosage) was the typical management in subtropical paddy field of China (Wang et al., 2015). We applied $8 \mathrm{Mg} \mathrm{ha}^{-1}$ because it is an intermediate dose in the range used in other previous experiments (Ali et al., 2008), and because this dose was earlier found to be the best one for reducing GHG emission and improving rice yield in this paddy field (Wang et al., 2015).

Our study was conducted at the Wufeng Agronomy Field of the Fujian Academy of Agricultural Sciences in Fujian Province, southeastern China $\left(26.1^{\circ} \mathrm{N}, 119.3^{\circ} \mathrm{E}, 40\right.$ $\mathrm{m}$ a.s.1) (Supplementary material Figure S1). The field experiment was carried out 
during the early paddy season (16 April to 16 July) in 2014. Air temperature and humidity during the studied period are shown in Figure S2. The soil of the paddy was poorly drained, and the proportions of sand, silt and clay particles in the top $15 \mathrm{~cm}$ of the soil were 28,60 and $12 \%$, respectively. Other properties of the top $15 \mathrm{~cm}$ of soil at the beginning of the experiment were: bulk density, $1.1 \mathrm{~g} \mathrm{~cm}^{-3}$; $\mathrm{pH}\left(1: 5\right.$ with $\left.\mathrm{H}_{2} \mathrm{O}\right), 6.5$; organic carbon $(\mathrm{C})$ concentration, $18.1 \mathrm{~g} \mathrm{~kg}^{-1}$; total nitrogen $(\mathrm{N})$ concentration, $1.2 \mathrm{~g}$ $\mathrm{kg}^{-1}$ and total phosphorus (P) concentration, $1.1 \mathrm{~g} \mathrm{~kg}^{-1}$. Crop was kept under flooding from 0 to 37 days after transplanting (DAT) and water level was maintained at $5-7 \mathrm{~cm}$ above the soil surface by an automatic water-level controller. Each plot was kept under drainage between 37-44 DAT. The soil of each treatment plot was then kept under moist conditions between 44-77 DAT. Finally, the paddy field was drained two weeks before harvest (77 DAT). Rice (Oryza sativa) was harvested at 92 DAT.

We established triplicate plots $(10 \times 10 \mathrm{~m})$ for five treatments and control in which rice seedlings (Hesheng 10 cultivar) were transplanted to a depth of $5 \mathrm{~cm}$ with a spacing of $14 \times 28 \mathrm{~cm}$ using a rice transplanter. The soil of the fertilized plots received a dose of $8 \mathrm{Mg} \mathrm{ha}^{-1}$ with granules ( $2 \mathrm{~mm}$ in diameter) of the corresponding fertilizer type: steel slag, rice biochar, shell slag, gypsum slag or a silicate and calcium fertilizer produced from steel slag. The steel slag was collected from the Jinxing Iron \& Steel Co., Ltd in Fujian. The rice biochar was collected from the Qinfeng Straw Technology Co., Ltd in Jiangsu Province. The gypsum slag was collected from building waste (from indoordecoration of buildings). The silicate and calcium fertilizer was collected from the Ruifeng Silicon Fertilizer Co., Ltd in Henan Province. The industrial and agricultural wastes used in this study were rich in silicon, calcium and potassium, which are essential nutrients for rice growth (Wang et al., 2015). The chemical composition of these wastes is shown in Table S1.

All control and treatment plots received the same amount of water and fertilizer. The field was plowed to a depth of $15 \mathrm{~cm}$ with a moldboard plow and was leveled two days before rice transplantation immediately after plow. Mineral fertilizers were applied in three times as complete $\left(\mathrm{N}-\mathrm{P}_{2} \mathrm{O}_{5}-\mathrm{K}_{2} \mathrm{O}\right.$ at 16-16-16\%; Keda Fertilizer Co., Ltd.) and urea $(46 \% \mathrm{~N})$ fertilizers. The first application was one day before transplantation at

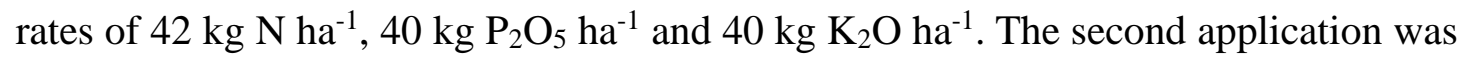
broadcasted during the tiller initiation stage (7 DAT) at rates of $35 \mathrm{~kg} \mathrm{~N} \mathrm{ha}^{-1}, 20 \mathrm{~kg}$ $\mathrm{P}_{2} \mathrm{O}_{5} \mathrm{ha}^{-1}$ and $20 \mathrm{~kg} \mathrm{~K}_{2} \mathrm{O} \mathrm{ha}^{-1}$. The third application was broadcasted during the panicle initiation stage (56 DAT) at rates of $18 \mathrm{~kg} \mathrm{~N} \mathrm{ha}^{-1}, 10 \mathrm{~kg} \mathrm{P}_{2} \mathrm{O}_{5} \mathrm{ha}^{-1}$ and $10 \mathrm{~kg} \mathrm{~K}_{2} \mathrm{O} \mathrm{ha}^{-1}$.

\section{Measurement of $\mathrm{CO}_{2}, \mathrm{CH}_{4}$ and $\mathrm{N}_{2} \mathrm{O}$ emissions}

Static closed chambers were used to measure $\mathrm{CO}_{2}, \mathrm{CH}_{4}$ and $\mathrm{N}_{2} \mathrm{O}$ emissions during the study period. The chambers were made of PVC and consisted of two parts, an upper transparent compartment $(100 \mathrm{~cm}$ height, $30 \mathrm{~cm}$ width, $30 \mathrm{~cm}$ length) placed on a permanently installed bottom collar $(10 \mathrm{~cm}$ height, $30 \mathrm{~cm}$ width, $30 \mathrm{~cm}$ length). Each chamber had two battery-operated fans to mix the air inside the chamber headspace, an internal thermometer to monitor temperature changes during gas sampling and a gassampling port with a neoprene rubber septum at the top of the chamber for collecting 
gas samples from the headspace. We deployed three replicate chambers in each treatment. A wooden boardwalk was built for accessing the plots to minimize disturbance of the soil during gas sampling.

Gas flux was measured weekly in all chambers. Gas samples were collected from the chamber headspace using a 100-mL plastic syringe with a three-way stopcock. The syringe was used to collect gas samples from the chamber headspace 0, 15 and $30 \mathrm{~min}$ after chamber installation. The samples were immediately transferred to $100-\mathrm{mL}$ airevacuated aluminum foil bags (Delin Gas Packaging Co., Ltd., Dalian, China) sealed with butyl rubber septa and transported immediately to the laboratory for the analysis of $\mathrm{CO}_{2}, \mathrm{CH}_{4}$ and $\mathrm{N}_{2} \mathrm{O}$.

$\mathrm{CO}_{2}, \mathrm{CH}_{4}$ and $\mathrm{N}_{2} \mathrm{O}$ concentrations in the headspace air samples were determined by gas chromatography using a stainless steel Porapak Q column ( 2 m length, $4 \mathrm{~mm}$ OD, 80/100 mesh). $\mathrm{CO}_{2}$ and $\mathrm{CH}_{4}$ were analyzed in a Shimadzu GC-2010, whereas $\mathrm{N}_{2} \mathrm{O}$ was evaluated with a Shimadzu GC-2014, Kyoto, Japan. A methane conversion furnace, flame ionization detector (FID) and electron capture detector (ECD) were used for the determination of the $\mathrm{CO}_{2}, \mathrm{CH}_{4}$ and $\mathrm{N}_{2} \mathrm{O}$ concentrations, respectively. The operating temperatures of the column, injector and detector for the determination of $\mathrm{CO}_{2}, \mathrm{CH}_{4}$ and $\mathrm{N}_{2} \mathrm{O}$ were adjusted to 45,100 and $280{ }^{\circ} \mathrm{C}$; to 70,200 and $200{ }^{\circ} \mathrm{C}$ and to 70,200 , and $320^{\circ} \mathrm{C}$, respectively. Helium $(99.999 \%$ purity) was used as a carrier gas $(30 \mathrm{~mL}$ $\mathrm{min}^{-1}$ ), and a make-up gas (95\% argon and 5\% $\mathrm{CH}_{4}$ ) was used for the ECD. The gas chromatograph was calibrated before and after each set of measurements using 503, 1030 and $2980 \mu \mathrm{L} \mathrm{CO}_{2} \mathrm{~L}^{-1}$ in $\mathrm{He}$; $1.01,7.99$ and $50.5 \mu \mathrm{L} \mathrm{CH}_{4} \mathrm{~L}^{-1}$ in $\mathrm{He}$ and $0.2,0.6$ and $1.0 \mu \mathrm{L} \mathrm{N}_{2} \mathrm{O} \mathrm{L}^{-1}$ in $\mathrm{He}\left(\mathrm{CRM} / \mathrm{RM}\right.$ Information Center of China) as standards. $\mathrm{CO}_{2}$, $\mathrm{CH}_{4}$ and $\mathrm{N}_{2} \mathrm{O}$ fluxes were then calculated as the rate of change in the mass of $\mathrm{CO}_{2}, \mathrm{CH}_{4}$ and $\mathrm{N}_{2} \mathrm{O}$ per unit of surface area and per unit of time. Three different injections were used for each analysis. One sample was injected to the GC for each analysis. The detection range of the instrument for $\mathrm{CO}_{2}$ was $1 \mathrm{ppm}, \mathrm{CH}_{4}$ was $0.1 \mathrm{ppm}, \mathrm{N}_{2} \mathrm{O}$ was 0.05 ppm. We used linear calculation for $\mathrm{CO}_{2}, \mathrm{CH}_{4}$ and $\mathrm{N}_{2} \mathrm{O}$ fluxes.

\section{Global warming potential (GWP)}

To estimate GWP, $\mathrm{CO}_{2}$ is typically taken as the reference gas, and a change in the emission of $\mathrm{CH}_{4}$ or $\mathrm{N}_{2} \mathrm{O}$ is converted into " $\mathrm{CO}_{2}$-equivalents". The GWP for $\mathrm{CH}_{4}$ is 34 (based on a 100-year time horizon and a GWP for $\mathrm{CO}_{2}$ of 1), and the GWP for $\mathrm{N}_{2} \mathrm{O}$ is 298. The GWP of the combined emission of $\mathrm{CH}_{4}$ and $\mathrm{N}_{2} \mathrm{O}$ was calculated according to Ahmad et al. (2009): GWP = (cumulative $\mathrm{CO}_{2}$ emission $\times 1+$ cumulative $\mathrm{CH}_{4}$ emission $\times 34+$ cumulative $\mathrm{N}_{2} \mathrm{O}$ emission $\left.\times 298\right)$.

\section{Measurement of soil properties}

Three sample replicates of soil for each treatment and also for control were collected. After collecting and transporting them to the laboratory, the samples were stored at $4{ }^{\circ} \mathrm{C}$ until analyses. Soil temperature, $\mathrm{pH}$, salinity, redox potential (Eh) and water content of the top $15 \mathrm{~cm}$ of soil were measured in triplicate in situ at each plot on each sampling time. Temperature, $\mathrm{pH}$ and Eh were measured with an $\mathrm{Eh} / \mathrm{pH} /$ Temperature meter (IQ Scientific Instruments, Carlsbad, USA), salinity was 
measured using a 2265FS EC meter (Spectrum Technologies Inc., Paxinos, USA) and water content was measured using a TDR 300 meter (Spectrum Field Scout Inc., Aurora, USA). We also collected soil samples from the $0-15 \mathrm{~cm}$ layer from each plot for the determination of ferric, ferrous and total Fe contents. Total Fe content was determined by digesting fresh soil samples with $1 \mathrm{M} \mathrm{HCl}$. Ferrous ions were extracted using 1,10phenanthroline and measured spectrometrically (Wang et al., 2015). Ferric concentration was calculated by subtracting the ferrous concentration from the total $\mathrm{Fe}$ concentration.

\section{Statistical analysis}

Differences in soil properties and $\mathrm{CO}_{2}, \mathrm{CH}_{4}$ and $\mathrm{N}_{2} \mathrm{O}$ emissions among the fertilization treatments and controls were tested for statistical significance by repeatedmeasures analyses of variance (RM-ANOVAs). The relationships between mean GHG emissions and soil properties were determined by Pearson correlation analysis. These statistical analyses were performed using SPSS Statistics 18.0 (SPSS Inc., Chicago, USA).

We also performed multivariate statistical analyses using general discriminant analysis (GDA) to determine the overall differences of soil salinity, $\mathrm{pH}$, water content, redox potential (Eh) and temperature between fertilization treatments and sampling dates. We also assessed the component of the variance due to the sampling time as an independent categorical variable. Discriminant analyses consist of a supervised statistical algorithm that derives an optimal separation between groups established a priori by maximizing between-group variance while minimizing within-group variance. GDA is thus an appropriate tool for identifying the variables most responsible for the differences among groups while controlling the component of the variance due to other categorical variables. The GDAs were performed using Statistica 8.0 (StatSoft, Inc., Tulsa, USA). We used structural equation modelling (SEM) to identify the factors explaining the maximum variability of the $\mathrm{CO}_{2}, \mathrm{CH}_{4}$ and $\mathrm{N}_{2} \mathrm{O}$ emissions and rice yield throughout the study period as functions of the soil-amendment treatments to detect total, direct and indirect effects of the amendment treatments on $\mathrm{CO}_{2}, \mathrm{CH}_{4}$ and $\mathrm{N}_{2} \mathrm{O}$ emissions and rice yield. SEMs allow the detection of indirect effects on the soil traits (water content, temperature, salinity, $\mathrm{pH}, \mathrm{Eh},\left[\mathrm{Fe}^{2+}\right]$ and $\left[\mathrm{Fe}^{3+}\right]$ ) due to the amendment treatments that can be correlated with $\mathrm{CO}_{2}, \mathrm{CH}_{4}$ and $\mathrm{N}_{2} \mathrm{O}$ emissions and rice yield. We fit the models using the sem R package (Fox et al., 2013) and acquired the minimally adequate model using the Akaike information criterion. Standard errors and significance levels of the direct, indirect and total effects were calculated by bootstrapping (1200 repetitions).

\section{RESULTS}

\section{$\mathrm{CO}_{2}, \mathrm{CH}_{4}$ and $\mathrm{N}_{2} \mathrm{O}$ emissions from the paddy}

Plots fertilized with steel slag, biochar, gypsum slag and the silicate and calcium fertilizer had significantly 20.2, 20.6, 22.2 and 21.4\% lower mean $\mathrm{CO}_{2}$ emissions than 
the control plots $(P<0.05$, Tables 1 and $\mathrm{S} 2)$. Mean $\mathrm{CO}_{2}$ emissions in shell slag plots did not differ significantly from those in the control plots $(P>0.05) . \mathrm{CO}_{2}$ emission varied significantly among treatments and sampling dates, and the steel slag and biochar treatments had significant interactions with time $\left(P<0.01\right.$, Table S2). $\mathrm{CO}_{2}$ flux generally remained low $\left(<254 \mathrm{mg} \mathrm{m}^{-2} \mathrm{~h}^{-1}\right)$ during the first 29 DAT but then increased to a seasonal peak (>1296 $\mathrm{mg} \mathrm{m}^{-2} \mathrm{~h}^{-1}$ ) at 71 DAT (Figure $1 \mathrm{~A}$ ). The rice was nearly ripe by $71 \mathrm{DAT}$, with a corresponding decrease in $\mathrm{CO}_{2}$ emissions until harvesting in July.

Steel slag, biochar, shell slag and gypsum slag fertilized plots had 53.8, 66.7, 62.7 and $81.5 \%$ lower mean $\mathrm{CH}_{4}$ emissions than those in the control plot $(P<0.05$, Table $\mathrm{S} 2$ ). Mean $\mathrm{CH}_{4}$ emissions in plots fertilized with the silicate and calcium fertilizer did not differ significantly from those in the control plots $(P>0.05)$. Maximum fluxes were earlier in the control plots than in treatments (Figure 1B). The $\mathrm{CH}_{4}$ flux peaked by 43 DAT in the plots amended with gypsum slag and the silicate and calcium fertilizer and peaked by 71 DAT in the steel slag, biochar and shell slag treatments. The paddy was drained after the rice reached maturity, with $\mathrm{CH}_{4}$ emissions decreasing until rice harvest in July.

Plots with biochar had lower $\mathrm{N}_{2} \mathrm{O}$ emissions (by $56.5 \%$ ) in comparison with control $\left(P<0.05\right.$, Tables 1 and S2). Mean $\mathrm{N}_{2} \mathrm{O}$ emission was higher in the control plots $(-14.3$ $\left.\mu \mathrm{g} \mathrm{m}^{-2} \mathrm{~h}^{-1}\right)$, and in shell slag and steel slag than in the gypsum slag $\left(-144 \mu \mathrm{g} \mathrm{m}^{-2} \mathrm{~h}^{-1}\right)$ and silicate and calcium $\left(-75.3 \mu \mathrm{g} \mathrm{m}^{-2} \mathrm{~h}^{-1}\right)$ fertilizer treatments 57 DAT. Mean $\mathrm{N}_{2} \mathrm{O}$ emission was higher in the steel slag treatment $\left(-68.9 \mu \mathrm{g} \mathrm{m}^{-2} \mathrm{~h}^{-1}\right)$ and control than in biochar treatment 71 DAT (Figure 1C). Mean $\mathrm{N}_{2} \mathrm{O}$ emission was lowest in the biochar treatment (-97.3 $\left.\mu \mathrm{g} \mathrm{m}^{-2} \mathrm{~h}^{-1}\right)$ than in all other treatments and control 92 DAT (Figure 1C). The negative values of $\mathrm{N}_{2} \mathrm{O}$ emission were because our study site was strongly limited by $\mathrm{N}$, and in such conditions $\mathrm{N}_{2} \mathrm{O}$ is reduced to $\mathrm{NH}_{4}{ }^{+}$, thus, the soils acted as sink of $\mathrm{N}_{2} \mathrm{O}$ in all treatments.

The cumulative $\mathrm{CO}_{2}$ and $\mathrm{CH}_{4}$ emissions during the studied period were lower in all treatments than in control plots (Figure 2A, B). The plots fertilized with biochar, shell slag, gypsum slag and $\mathrm{Si}$ plus $\mathrm{Ca}$ fertilizer had also lower cumulative $\mathrm{N}_{2} \mathrm{O}$ emissions than control plots during the studied period (Figure 2C). The average rice yield was higher in the plots fertilized with steel slag, biochar and shell slag compared to the control treatment (Table 1). The GWP was higher for $\mathrm{CO}_{2}$ than for $\mathrm{CH}_{4}$ and $\mathrm{N}_{2} \mathrm{O}$ emissions, with a contribution $>80 \%$. The total GWPs for all emissions were 26.6, 29.8, 25.9, 34.2 and $26.7 \%$ lower in the steel slag, biochar, shell slag, gypsum slag and silicate and calcium fertilizer treatments, respectively, compared to the control. Compared to the control, the total GWPs per unit yield were lower in the steel slag, biochar, shell slag and silicate and calcium fertilizer treatments by $31.4,39.25,30.4$ and $29.0 \%$, respectively

\section{Differences in soil properties among plots with different fertilization treatments}

Soil $\mathrm{pH}$, Eh, temperature, salinity, water content and ferrous, ferric and total $\mathrm{Fe}$ concentrations varied throughout the growing season $(P<0.001$; Figure 3, Table S3). Soil $\mathrm{pH}$ was higher in the plots with steel slag, biochar, shell slag and the silicate and 
calcium fertilizer compared to the control treatment $(P<0.05)$. Soil Eh and total Fe concentration were higher in the plots with steel slag, biochar, gypsum slag and the silicate and calcium fertilizer compared to the control $(P<0.05)$. Soil temperature was higher in the plots with gypsum slag compared to the control $(P<0.05)$. Soil salinity was higher in the plots with steel slag, shell slag, gypsum slag and the silicate and calcium fertilizer compared to the control $(P<0.05)$. Soil water content was higher in the plots with steel slag, biochar, gypsum slag and the silicate and calcium fertilizer compared to the control $(P<0.05)$. Soil $\mathrm{Fe}^{2+}$ concentration was higher in the plots with steel slag, biochar and the silicate and calcium fertilizer compared to the control $(P<0.05)$. Soil $\mathrm{Fe}^{3+}$ concentration was higher in the plots with biochar, shell slag, gypsum slag and the silicate and calcium fertilizer compared to the control $(P<0.05)$.

\section{Relationships between $\mathrm{CO}_{2}, \mathrm{CH}_{4}$ and $\mathrm{N}_{2} \mathrm{O}$ emissions and soil properties}

Seasonal $\mathrm{CO}_{2}$ emission was positively correlated with soil temperature in all plots ( $R=0.81-0.88, P<0.01$, Table S4); positively correlated with soil Eh in the biochar, shell slag, gypsum slag and the silicate and calcium fertilizer treatments $(R=0.29-0.40$, $P<0.05)$; positively correlated with soil water content in the control and the steel slag, biochar, gypsum slag and silicate and calcium fertilizer treatments $(R=0.28-0.46$, $P<0.05)$; positively correlated with soil $\mathrm{Fe}^{2+}$ concentration only in the control plot $(R=$ $0.35, P<0.05)$ and negatively correlated with soil $\mathrm{pH}$ in the control and the biochar, shell slag, gypsum slag and silicate and calcium fertilizer treatments $(R=-0.28$ to -0.63 , $P<0.05)$.

Seasonal $\mathrm{CH}_{4}$ emission was positively correlated with soil salinity $(R=0.27-0.65$, $P<0.05$, Table S4) and water content in all plots $(R=0.28-0.67, P<0.01)$, positively correlated with soil $\mathrm{Fe}^{2+}$ concentration in the shell slag, gypsum slag and silicate and calcium fertilizer treatments $(R=0.26-0.44, P<0.05)$ and positively correlated with soil $\mathrm{Fe}^{3+}$ and total $\mathrm{Fe}$ concentration in the silicate and calcium fertilizer treatment $(R=0.50$ and $0.44, P<0.05)$.

Seasonal $\mathrm{N}_{2} \mathrm{O}$ emission was positively correlated with soil salinity in the biochar treatment $(R=0.46, P<0.05$, Table $\mathrm{S} 4)$, positively correlated with soil $\mathrm{Fe}^{3+}$ and total $\mathrm{Fe}$ concentration in the steel slag treatment $(R=0.30$ and $0.27, P<0.05)$ and negatively correlated with soil water content and $\mathrm{Fe}^{2+}, \mathrm{Fe}^{3+}$ and total $\mathrm{Fe}$ concentrations in the silicate and calcium fertilizer treatment $(R=-0.32$ to $-0.42, P<0.05)$.

\section{Discriminant General Analyses (DGA)}

The DGA conducted with soil $\mathrm{pH}$, Eh, temperature, salinity, water content and $\mathrm{Fe}^{2+}$ and $\mathrm{Fe}^{3+}$ concentrations and the $\mathrm{CO}_{2}, \mathrm{CH}_{4}$ and $\mathrm{N}_{2} \mathrm{O}$ emissions as independent continuous variables, sampling time as the categorical independent variable and plots receiving the fertilization treatments as the categorical dependent variable indicated statistical differences among all treatments except between the biochar and the steel slag and shell slag treatments (Table S5, Figure 4). Soil pH, Eh, salinity, water content and $\mathrm{Fe}^{2+}$ and $\mathrm{Fe}^{3+}$ concentrations and the $\mathrm{CO}_{2}, \mathrm{CH}_{4}$ and $\mathrm{N}_{2} \mathrm{O}$ emissions contributed significantly to these separations in this GDA model (Table S6). 
The SEM analyses identified some of the soil variables underlying the relationships between the fertilization treatments and $\mathrm{CO}_{2}, \mathrm{CH}_{4}$ and $\mathrm{N}_{2} \mathrm{O}$ emissions. The negative relationship between steel slag fertilization and $\mathrm{CO}_{2}$ emission was due to direct negative effect plus and indirect positive relationships with soil $\mathrm{Fe}^{2+}$ concentration that in turn was negatively associated with $\mathrm{CO}_{2}$ emission (Figure S3A, S4A). The negative direct relationship of steel slag fertilization with $\mathrm{CH}_{4}$ emission was partially counteracted by a positive relationship of the steel slag fertilization with soil salinity, which thereafter was positively associated with $\mathrm{CH}_{4}$ emission (Figure S3B,S4B). Biochar fertilization had negative relationships with $\mathrm{CO}_{2}, \mathrm{CH}_{4}$ and $\mathrm{N}_{2} \mathrm{O}$ emissions. These negative relationships in the case of $\mathrm{CH}_{4}$ and $\mathrm{N}_{2} \mathrm{O}$ emissions were slightly counteracted by an indirect positive effect through the positive relationship of biochar fertilization with soil salinity (Figure S5A-C,S6A-C). Biochar fertilization had a strong positive relationship with rice yield that was slightly counteracted by the negative relationship of biochar fertilization with $\mathrm{CH}_{4}$ emission (Figure S5D,S6D).

As with biochar fertilization, shell slag fertilization was negatively correlated with $\mathrm{CH}_{4}$ emission, but this direct negative relationship was counteracted by an indirect positive effect of shell slag fertilization with soil salinity (Figure S7,S8), finally resulting in absence of any global total effect. The gypsum slag and silicate and calcium fertilizer treatments also had negative direct relationships with $\mathrm{CO}_{2}$ and $\mathrm{CH}_{4}$ emissions. These negative direct relationships were partially but significantly counteracted by an indirect positive effect of the gypsum slag and silicate and calcium fertilizer treatments on soil water content (Figures S9-S12).

\section{DISCUSSION}

\section{Effects of treatments on $\mathrm{CO}_{2}$ emissions}

$\mathrm{CO}_{2}$ emission varied seasonally (Figure 1A), changing with rice growth and temperature (Figure 3). Temperature controls $\mathrm{CO}_{2}$ production and emission (Asensio et al., 2012) by not only increasing soil microbial activity, but also by altering plant respiration (Slot et al., 2013). In our study, the steel slag, biochar, gypsum slag and silicate and calcium fertilizer treatments significantly decreased $\mathrm{CO}_{2}$ emissions (Figure 2A). These fertilizers are all alkaline and then increase soil $\mathrm{pH}$, facilitating the absorption of $\mathrm{CO}_{2}$ by water through the carbonate-bicarbonate buffer system (Revell et al., 2012). The steel slag, gypsum slag and silicate and calcium fertilizer are also rich in $\mathrm{Ca}^{2+}$, which can combine with $\mathrm{CO}_{2}$ to form $\mathrm{CaCO}_{3}$. Such product is deposited in the soil and decreases $\mathrm{CO}_{2}$ emission (Phillips et al., 2013).

Soil $\mathrm{Fe}^{3+}$ concentration also increased in the steel slag and silicate and calcium fertilizer treatments (Figure $3 \mathrm{G}$ and $3 \mathrm{H}$ ), thereby enhancing the formation of iron plaque on the rice roots and thus limiting the transport of nutrients, water and soil dissolved organic carbon (DOC) to rice roots (Huang et al., 2012). Iron plaques decrease root ventilation, so less $\mathrm{CO}_{2}$ is transported through the internal system of interconnected gas lacunae of the plants. Moreover, when soil $\mathrm{Fe}^{3+}$ concentration increases, the rate of $\mathrm{Fe}^{3+}$ reduction also increases. Then, reduced $\mathrm{Fe}^{2+}$ accumulates 
in the soil (Wang et al., 2015) and inhibits microbial activity, lowering $\mathrm{CO}_{2}$ emissions (Huang et al., 2009). The steel slag treatment accordingly had an indirect effect on $\mathrm{CO}_{2}$ emissions by increasing soil $\mathrm{Fe}^{2+}$ concentrations.

The gypsum slag fertilization treatment increased soil $\mathrm{SO}_{4}{ }^{2-}$ (Chen et al., 2013) thereby increasing the rate of $\mathrm{SO}_{4}{ }^{2-}$ reduction and its accumulation in the soil. Higher sulfide concentrations in soil can inhibit microbial activity and subsequently decrease $\mathrm{CO}_{2}$ emissions (Chen et al., 2013). The gypsum slag and silicate and calcium fertilizer treatments decreased $\mathrm{CO}_{2}$ emissions, an effect also associated with increases in soil water content. Linn and Doran (1984) reported that soil water contents $>60 \%$ decreased aerobic microbial activity and increased anaerobic processes, which decreased $\mathrm{CO}_{2}$ production and emission. In our study, the average water content in the control, gypsum slag and silicate and calcium fertilizer treatments were all $>60 \%$ during the growing season: $62 \%$ in the control plots and $80 \%$ and $69 \%$ in the gypsum slag and silicate and calcium fertilizer treatments, respectively (Figure 3E and 3F). Biochar fertilization also reduced $\mathrm{CO}_{2}$ emission, which is in accordance with previous research (Revell et al., 2012). Biochar is highly stable, has a high capacity to absorb atmospheric $\mathrm{CO}_{2}$ and can remain in the soil for long periods (Zhang et al., 2010; Revell et al., 2012).

The GDA (Figure 4) and SEM (Figures S3-S12) analyses indicated that all fertilization treatments had some positive effects on $\mathrm{CO}_{2}$ and $\mathrm{CH}_{4}$ emissions by increasing soil salinity and water content. However, these indirect positive effects, although significant, were not large enough to prevent the total negative relationships with the $\mathrm{CO}_{2}$ and $\mathrm{CH}_{4}$ emissions (Figures S3-S12). Biochar amendment also increased the soil C:N ratio. Higher $\mathrm{C}: \mathrm{N}$ ratios are associated with limited $\mathrm{N}$ availability, which impedes mineralization and stabilizes microbial biomass carbon (Revell et al., 2012), thereby lowering $\mathrm{CO}_{2}$ emissions (Chen et al., 2013). In fact, decreases in the release of $\mathrm{N}$ and $\mathrm{P}$ from litter have been associated with sudden decreases in $\mathrm{CO}_{2}$ emissions (Asensio et al., 2012).

\section{Effects of treatments on $\mathrm{CH}_{4}$ emissions}

$\mathrm{CH}_{4}$ emission varied seasonally (Figure 1B), with emissions of $\mathrm{CH}_{4}$ being low soon after rice transplantation when the soil was not strictly anaerobic. $\mathrm{CH}_{4}$ emissions were also lower during the final ripening and drainage periods. These results agreed with those by Minamikawa et al. (2014), in which a lowering of the water table decreased the abundance of the methanogenic archaeal population and hence $\mathrm{CH}_{4}$ production and increased the abundance of methanotrophs and thus $\mathrm{CH}_{4}$ oxidation.

Both $\mathrm{Fe}^{3+}$ and $\mathrm{SO}_{4}{ }^{2-}$ are alternative electron acceptors that will use $\mathrm{C}$ substrates before methanogens (Jiang et al., 2013) thus decreasing the amount of $\mathrm{CH}_{4}$ production (Ali et al., 2008), which compete with methanogens for C substrates (Jiang et al., 2013). The steel and gypsum slag treatments increased Eh, which is also consistent with the decrease in $\mathrm{CH}_{4}$ emissions. Recent studies have found that the presence of ferric iron and sulfate can support the oxidation of $\mathrm{CH}_{4}$ under anaerobic conditions (Wang et al., 2015). Fertilization with steel and gypsum slags would thus decrease the release of $\mathrm{CH}_{4}$ 
to the atmosphere as a result of a decrease in $\mathrm{CH}_{4}$ production, an increase in $\mathrm{CH}_{4}$ oxidation, or both (Wang et al., 2015).

Biochar can also reduce $\mathrm{CH}_{4}$ emissions (Figure 2B), as previously reported (Zhang et al., 2010; Revell et al., 2012). Biochar amendment increases soil ventilation (Revell et al., 2012), which increases methane oxidation and thus decreases methane production. Biochar fertilization also decreases and stabilizes the microbial biomass carbon, which may also account for decreases in $\mathrm{CH}_{4}$ emission (Revell et al., 2012). Furthermore, biochar is very stable, highly porous and can absorb $\mathrm{CH}_{4}$ (Zhang et al., 2010; Revell et al., 2012) and increase the oxidation of $\mathrm{CH}_{4}$ (Revell et al., 2012). As consequence, the soil fertilized with biochar in our study released low amounts of $\mathrm{CH}_{4}$. The shell slag also decreased $\mathrm{CH}_{4}$ emission but increased soil salinity due to its marine origin.

\section{Effects of fertilization treatments on $\mathrm{N}_{2} \mathrm{O}$ emissions}

$\mathrm{N}_{2} \mathrm{O}$ emission had no obvious patterns of seasonal variation. $\mathrm{N}_{2} \mathrm{O}$ emission was low throughout the growing season. The paddies in our study region are strongly $\mathrm{N}$ limited (Wang et al., 2015), so together with the low levels of soil $\mathrm{O}_{2}$, most of the $\mathrm{N}_{2} \mathrm{O}$ produced is likely reduced to $\mathrm{N}_{2}$, which would lead to the apparently very low emissions or even a net uptake of $\mathrm{N}_{2} \mathrm{O}$ (Zhang et al., 2010).

Biochar significantly decreased $\mathrm{N}_{2} \mathrm{O}$ emission, as previously reported (Cayuela et al., 2010). Biochar is rich in alkaline material, so it can increase soil $\mathrm{pH}$, stimulate $\mathrm{N}_{2} \mathrm{O}$ reductase activity and thereby induce $\mathrm{N}_{2} \mathrm{O}$ reduction to $\mathrm{N}_{2}$ (Cayuela et al., 2010). The porous structure of biochar can also absorb $\mathrm{NH}_{4}{ }^{+}-\mathrm{N}$ and $\mathrm{NO}_{3}{ }^{-}-\mathrm{N}$ from soil solution, thereby inhibiting nitrification and denitrification and thus decreasing $\mathrm{N}_{2} \mathrm{O}$ emission (Cayuela et al., 2010). Biochar may also improve soil aeration and impede the function and diversity of denitrifying bacteria, thereby decreasing $\mathrm{N}_{2} \mathrm{O}$ emission (Zhang et al., 2010).

Steel slag, shell slag, gypsum slag and the silicate and calcium fertilizer also decreased $\mathrm{N}_{2} \mathrm{O}$ emissions. Our experiment, however, was conducted within a single growing season, and the variation in $\mathrm{N}_{2} \mathrm{O}$ emission within a treatment group was quite large, so identifying a discernible effect of the different fertilization treatments on mean $\mathrm{N}_{2} \mathrm{O}$ emissions was difficult. The lack of significant decreases in $\mathrm{N}_{2} \mathrm{O}$ emission by an amendment material likely has several causes. Steel slag and the silicate and calcium fertilizer are rich in $\mathrm{Fe}^{3+}$, which would increase the soil $\mathrm{Fe}^{3+}$ concentration. Huang et al. (2009) suggested that soil $\mathrm{Fe}^{3+}$ concentration was one of the most sensitive factors regulating $\mathrm{N}_{2} \mathrm{O}$ emissions from paddies. $\mathrm{Fe}^{3+}$ concentrations and $\mathrm{N}_{2} \mathrm{O}$ emissions, however, were not correlated in our study. A previous study reported both positive and negative correlations between $\mathrm{Fe}^{3+}$ concentrations and $\mathrm{N}_{2} \mathrm{O}$ production, which were due to different soil conditions and hence the presence of various forms of $\mathrm{Fe}^{3+}$ (active, $\mathrm{Fe}^{3+}$ and complex ferric oxide, $\mathrm{Fe}_{2} \mathrm{O}_{3}$ ) (Huang et al., 2009).

The absence of a consistent effect of the steel slag and silicate and calcium fertilizer on $\mathrm{N}_{2} \mathrm{O}$ flux from the paddy could be attributed an inhibition of the enzymatic reduction of $\mathrm{N}_{2} \mathrm{O}$ by higher levels of $\mathrm{Fe}^{3+}$ increasing $\mathrm{N}_{2} \mathrm{O}$ release or an atmospheric inhibition of the enzymatic reduction of $\mathrm{N}_{2} \mathrm{O}$ in soils (Huang et al., 2009), an increase 
in the production of hydroxylamine by the biological oxidation of ammonia favored by higher $\mathrm{Fe}^{3+}$ concentrations and the further reaction of hydroxylamine with $\mathrm{Fe}^{3+}$ to generate $\mathrm{N}_{2} \mathrm{O}$ (Noubactep, 2011). The increase in $\mathrm{Fe}^{2+}$ concentrations by direct release from fertilizers or by microbial reduction (Ali et al., 2008) can further promote the reduction of nitrites to $\mathrm{N}_{2} \mathrm{O}$ (Hansen et al., 1994).

Gypsum slag is rich in $\mathrm{SO}_{4}{ }^{2-}$, which has the same function as $\mathrm{Fe}^{3+}$ in $\mathrm{N}$ cycling. The gypsum slag decreased $\mathrm{N}_{2} \mathrm{O}$ emission during the period of continuous flooding and slightly increased $\mathrm{N}_{2} \mathrm{O}$ emission in the drained paddy field. These results are consistent with the expected competition between $\mathrm{SO}_{4}{ }^{2-}$ as $\mathrm{NO}_{3}{ }^{-}$as electron acceptor in denitrification process under the anaerobic conditions of a flooded paddy (Yavitt et al., 1987). Thus, the relationships of the gypsum slag with $\mathrm{N}_{2} \mathrm{O}$ emissions changed depending on the period: during the flooded (decrease) and drained (increase) as a consequence the gypsum slag did not significantly decrease overall $\mathrm{N}_{2} \mathrm{O}$ emissions throughout the entire growing season.

\section{Best management practices to reduce GWP}

Our results suggested that the application of steel slag, biochar, shell slag and a silicate and calcium fertilizers all effectively reduced the adverse impacts of rice agriculture on climate change, with lower total GWPs per unit yield compared to the control treatment. The alkalinity of the steel slag, biochar, shell slag and the silicate and calcium fertilizer also improved the soil quality in this rice-producing area impacted by acid deposition. The rice biochar was rich in $\mathrm{N}$ in our study, thereby after rice biochar amendment, the plots had higher soil N-concentration than the control plots (Wang et al. unpublished data, Wang et al., 2016), which may have ultimately lead to higher grain yield from the treatment. Moreover, such as observed in previous studies, the application to soil of all the studied wastes have proved to increase soil N, P and S availability in pore-water and also to prevent the losses of these elements by leaching (Wang et al. 2016) with the consequent improving in soil fertility.

This study was based only on the results in a very important but short time-period. More studies are thus warranted to assure the suitability of the effects of the application of industrial and agricultural wastes tin other crop periods such ad late rice crop. Moreover, some of these wastes can introduce pollutants (such as heavier metal) to environment, and this should be also assessed. However, some of our previous studies showed that steel slag application to rice crops in equivalents doses to those of this study did not significantly impact on the heavy metals concentrations in soil and in rice yields (Wang et al., 2015b). A continuous application of wastes in the paddy field, could drive to decrease soil bulk density and consequently rise soil pore diameter, which will increase the loss of water and nutrients and thus be detrimental to rice growth (Zhao, 2012). However, the $8 \mathrm{Mg} \mathrm{ha}^{-1}$ waste amendment had increased the water content and porewater nutrient concentrations (Wang et al., 2016). (Wang et al., 2016).

The fertilizer materials chosen for this study were in abundant supply for application to rice paddies. They also have a low cost and recycle wastes. In a sustainable agriculture, steel slag, biochar, shell slag and silicate and calcium fertilizers 
can all increase $\mathrm{C}$ sequestration by paddy soils, improve soil fertility, increase rice yields and mitigate GHG emissions. Our results thus provide strong evidence for several benefits from the application of these industrial and agricultural wastes in rice fields.

Acknowledgments. The authors would like to thank Hongchang Ren, Xuming Wang and Qinyang Ji for their assistance with field sampling. Funding was provided by the National Science Foundation of China (41571287, 31000209), Natural Science Foundation Key Programs of Fujian Province (2014R1034-3, 2014 Y0054 and 2014J01119), the Program for Innovative Research Team at Fujian Normal University (IRTL1205), the European Research Council Synergy grant ERC-SyG-2013-610028 IMBALANCE-P, the Spanish Government grant CGL2013-48074-P and the Catalan Government grant SGR 2014-274.

\section{REFERENCES}

Ahmad, S., Li, C., Dai, G., Zhan, M., Wang, J., Pan, S. and Cao, C. (2009). Greenhouse gas emission from direct seeding paddy field under different rice tillage systems in central China. Soil \& Tillage Research 106: 54-61.

Ali, M.A., Oh, J.H. and Kim, P.J. (2008). Evaluation of silicate iron slag amendment on reducing methane emission from flood water rice farming. Agriculture Ecosystems \& Environment 128: 21-26.

Asensio, D., Yuste, J.C., Mattana, S., Ribas, A., Llusià, J. and Peñuelas, J. (2012). Litter VOCs induce changes in soil microbial biomass $\mathrm{C}$ and $\mathrm{N}$ and largely increase soil $\mathrm{CO}_{2}$ efflux. Plant and Soil 360: 163-174.

Cayuela, M.L., Oenema, O., Kuikman, P.J., Bakker, P.R. and Van Groenigen, J.W. (2010). Bioenergy by-products as soil amendments? Implications for carbon sequestration and greenhouse gas emissions. Global Change Biology: Bioenergy 2: 201-213.

Chen, B.Y., Liu, S.Q., Huang, J.Y., Shiau, T.J. and Wang, Y.M. (2013). Reduction of carbon dioxide emission by using microbial fuel cells during wastewater treatment. Aerosol and Air Quality Research 13: 266-274.

FAO [Food and Agricultural Organization of the United Nations]. 2009 OECD-FAO Agricultural Outlook 2011-2030.

Fox, J., Nie, Z. and Byrnes, J. (2013). sem: Structural Equation Models.

Feng, Y.Z., Xu, Y.P., Yu, Y.C., Xie, Z.B. and Lin, X.G. (2012). Mechanisms of biochar decreasing methane emission from Chinese paddy soils. Soil Biology and Biochemistry 46: 80-88.

Hansen, H.C.B., Borggaard, O.K. and Sørensen, J. (1994). Evaluation of the free energy of formation of $\mathrm{Fe}$ (II)-Fe (III) hydroxide-sulphate (green rust) and its reduction of nitrite. Geochimica et Cosmochimica Acta 58: 2599-2608.

Huang, B., Yu, K. and Gambrell, R.P. (2009). Effects of ferric iron reduction and regeneration on nitrous oxide and methane emissions in a rice soil. Chemosphere 74: 481-486. 
Huang, Y., Chen, Z. and Liu, W. (2012). Influence of iron plaque and cultivars on antimony uptake by and translocation in rice (Oryza sativa L.) seedlings exposed to $\mathrm{Sb}$ (III) or Sb (V). Plant and Soil 352: 41-49.

Hütsch, B.W. (2001). Methane oxidation in non-flooded soils as affected by crop production. European Journal of Agronomy 14: 237-260.

Jiang, G., Sharma, K.R. and Yuan, Z. (2013). Effects of nitrate dosing on methanogenic activity in a sulfide-producing sewer biofilm reactor. Water Research 47: 17831792.

Linn, D.M. and Doran, J.W. (1984). Effect of water-filled pore space on carbon dioxide and nitrous oxide production in tilled and nontilled soils. Soil Science Society of America Journal 48: 1267-1272.

Minamikawa, K., Fumoto, T., Itoh, M., Hayano, M., Sudo, S. and Yagi, K. (2014). Potential of prolonged midseason drainage for reducing methane emission from rice paddies in Japan: a long-term simulation using the DNDC-Rice model. Biology and Fertility of Soils 50: 879-889.

Noubactep, C. (2011). On the mechanism of microbe inactivation by metallic iron. Journal of Hazardous Materials 198: 383-386.

Pernes-Debuyser, A. and Tessier, D. (2004). Soil physical properties affected by long-term fertilization. European Journal of Soil Science 55: 505-512.

Phillips, A.J., Lauchnor, E., Eldring, J., Esposito, R., Mitchell, A.C., Gerlach, R., Cunningham, A.B. and Spangler, L.H. (2013). Potential $\mathrm{CO}_{2}$ leakage reduction through biofilm-induced calcium carbonate precipitation. Environmental Science \& Technology 47: 142-149.

Revell, K.T., Maguire, R.O. and Agblevor, F.A. (2012). Influence of poultry litter biochar on soil properties and plant growth. Soil Science 177: 402-408.

Slot, M., Wright, S.J. and Kitajima, K. (2013). Foliar respiration and its temperature sensitivity in trees and lianas: in situ measurements in the upper canopy of a tropical forest. Tree Physiology 33: 505-515.

Wang, W., Sardans, J., Lai, D.Y.F., Wang, C., Zeng, C., Tong, C., Liang, Y. and Peñuelas, J. (2015a). Effects of steel slag application on greenhouse gas emissions and crop yield over multiple growing seasons in a subtropical paddy field in China. Field Crops Research 171: 146-156.

Wang, W.Q., Sardans, J., Zeng, C.S., Tong, C., Peñuelas, J. (2015b) Steel slag reduces methane and nitrous oxide emission and increases rice production in a paddy field area of southeast China Field Crop Research. 117: 146-156.

Wang, W., Zeng, C., Sardans, J., Wang, C., Zeng, D., Peñuelas, J. (2016). Amendment with industrial and agricultural wastes reduces surface-water nutrient loss and storage of dissolved greenhouse gases in a subtropical paddy field. Agriculture, Ecosystems and Environment 231: 296-303.

Wassmann, R. and Aulakh, M.S. (2000). The role of rice plants in regulating mechanisms of methane emissions. Biology and Fertility of Soils 31: 20-29.

Yavitt, J.B., Lang, G.E. and Wieder, R.K. (1987). Control of carbon mineralization to $\mathrm{CH}_{4}$ and $\mathrm{CO}_{2}$ in anaerobic, Sphagnum derived peat from Big Run Bog, West 
607

608

609

610

611

Virginia. Biogeochemistry 4: 141-157.

Zhang, A., Cui, L., Pan, G., Li, L., Hussain, Q., Zhang, X., Zheng, J. and Crowley, D. (2010). Effect of biochar amendment on yield and methane and nitrous oxide emissions from a rice paddy from Tai Lake plain, China. Agriculture, Ecosystems \& Environment 139: 469-475. 


\section{Tables}

Table 1. Effect of the different fertilization treatments on the global warming potential (GWP)

\begin{tabular}{|c|c|c|c|c|c|c|}
\hline \multirow[b]{2}{*}{ Treatment } & \multirow{2}{*}{$\begin{array}{r}\text { Rice yield } \\
\left(\mathrm{Mg} \mathrm{ha}^{-1}\right)\end{array}$} & \multicolumn{3}{|c|}{ GWP $\left(\mathrm{kg} \mathrm{CO}_{2}\right.$-eq ha $\left.{ }^{-1}\right)$} & \multirow{2}{*}{$\begin{array}{c}\text { GWP } \\
\left(\mathrm{kg} \mathrm{CO}_{2} \text {-eq ha }{ }^{-1}\right)\end{array}$} & \multirow{2}{*}{$\begin{array}{c}\text { GWP } \\
\left(\mathrm{kg} \mathrm{CO}_{2} \text {-eq }\right. \\
\left.\mathrm{Mg}^{-1} \text { yield }\right)\end{array}$} \\
\hline & & $\mathrm{CO}_{2}$ & $\mathrm{CH}_{4}$ & $\mathrm{~N}_{2} \mathrm{O}$ & & \\
\hline Control & $8.06 \pm 0.26 \mathrm{c}$ & $23569 \pm 423 a$ & $5385 \pm 1099 a$ & $165 \pm 15 \mathrm{a}$ & $29119 \pm 546 a$ & $3613 \pm 176 a$ \\
\hline Steel slag & $8.63 \pm 0.19 b$ & $18819 \pm 437 b$ & $2490 \pm 759 b c$ & $71.7 \pm 68.6 a b$ & $21381 \pm 473 b$ & $2477 \pm 104 b$ \\
\hline Biochar & $9.31 \pm 0.57 \mathrm{a}$ & $18726 \pm 1182 b$ & $1794 \pm 558 \mathrm{~d}$ & $-87.1 \pm 90.3 b$ & $20433 \pm 1132 b$ & $2195 \pm 693 b$ \\
\hline Shell slag & $8.58 \pm 0.24 b$ & $19590 \pm 2719 \mathrm{ab}$ & $2007 \pm 155 \mathrm{bcd}$ & $-11.2 \pm 68.5 b$ & $21586 \pm 2482 b$ & $2516 \pm 694 b$ \\
\hline Gypsum slag & $6.55 \pm 0.43 \mathrm{~d}$ & $18335 \pm 993 b$ & $995 \pm 323 \mathrm{e}$ & $-162 \pm 212 b$ & $19168 \pm 965 b$ & $2926 \pm 633 a b$ \\
\hline Silicate and calcium fertilizer & $8.32 \pm 0.31 b c$ & $18515 \pm 1784 b$ & $2956 \pm 298 b$ & $-109 \pm 144 b$ & $21358 \pm 1588 b$ & $2567 \pm 592 b$ \\
\hline
\end{tabular}

Different letters within a column indicate significant differences between the treatments and control plots $(P<0.05)$ obtained by Bonferroni's post hoc test. 
Figure legends

Figure 1. $\mathrm{CO}_{2}(\mathrm{~A}), \mathrm{CH}_{4}(\mathrm{~B})$ and $\mathrm{N}_{2} \mathrm{O}(\mathrm{C})$ emissions in control and treatment plots during the studied period. Error bars indicate one standard error of the mean of triplicate measurements. Different letters indicate significant differences $(P<0.05)$ between fertilization treatments.

Figure 2. Cumulative emissions of $\mathrm{CO}_{2}(\mathrm{~A}), \mathrm{CH}_{4}$ (B), $\mathrm{N}_{2} \mathrm{O}$ (C) cumulative emissions among control and treatment plots during the studied period. Error bars indicate one standard error of the mean of triplicate measurements. Different letters indicate significant differences $(P<0.05)$ between fertilization treatments.

Figure 3. Soil pH (A), Eh (B), temperature (C), salinity (D), water content (E), $\mathrm{Fe}^{2+}$ concentration $(\mathrm{F}), \mathrm{Fe}^{3+}$ concentration $(\mathrm{G})$ and total $\mathrm{Fe}$ concentration $(\mathrm{H})$ in the control and treatment plots. Error bars indicate one standard error of the mean of triplicate measurements. Different letters indicate significant differences $(P<0.05)$ between fertilization treatments.

Figure 4. Standardized canonical discriminant function coefficients for the root representing the gas emissions and soil variables as independent continuous variables, the days of sampling as a categorical independent variable and different grouping dependent factors corresponding to the fertilization treatments. Bars indicate the confidence intervals (95\%) of the scores of each grouping factor along Root 1 and Root 2 . 


\section{Supplementary Information}

Table S1. Characteristics of different waste amendments in this study. Between brackets there are the number of $\mathrm{kg}^{-1} \mathrm{ha}^{-1}$ of each element that represents 8 $\mathrm{Mg} \mathrm{ha}{ }^{-1}$ of the corresponding fertilization treatments.

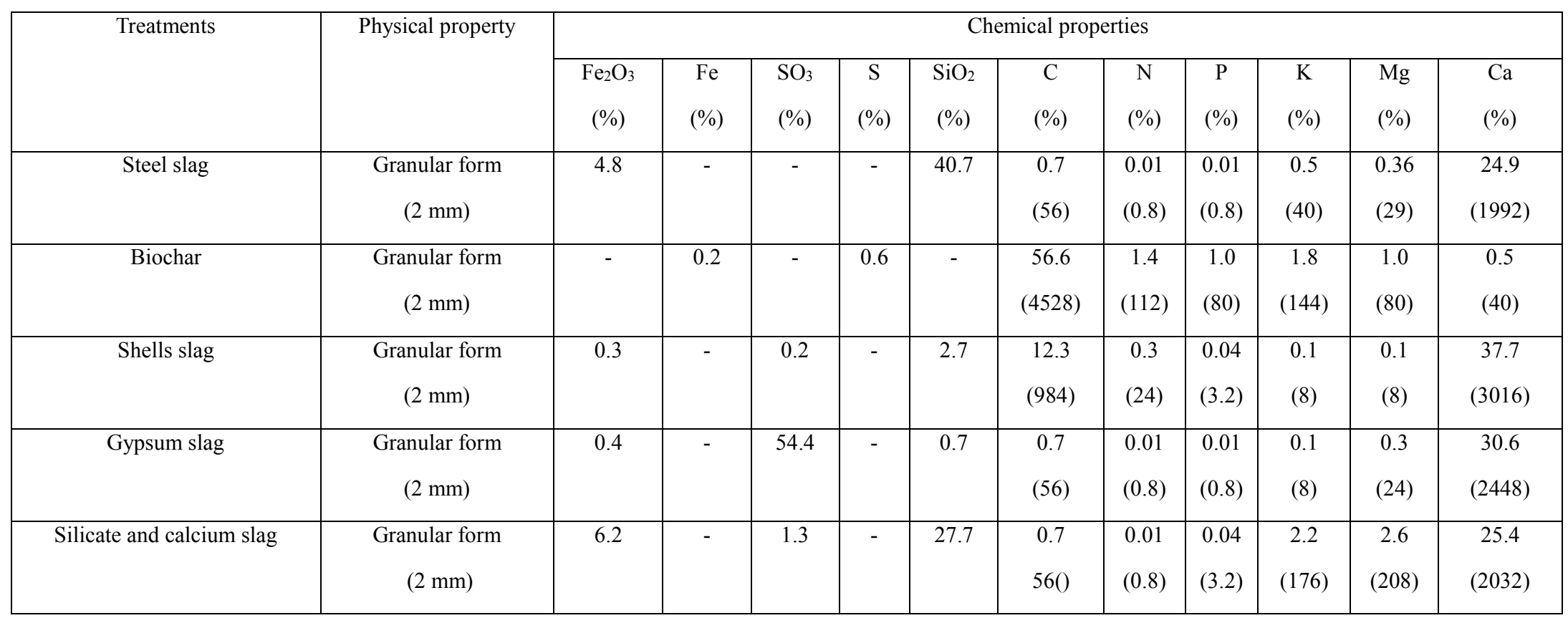


1 Table S2. Summary of the RM-ANOVAs for the greenhouse-gas emissions for the various 2 amendments.

\begin{tabular}{|c|c|c|c|c|}
\hline & $d f$ & $M S$ & $F$ & $P$ \\
\hline \multicolumn{5}{|l|}{$\mathrm{CO}_{2}$} \\
\hline Steel slag & 1,4 & 971987.40 & 60.94 & 0.001 \\
\hline Time & 13,52 & 3888621.81 & 70.40 & $<0.001$ \\
\hline Steel $\times$ Time & 13,52 & 116676.42 & 2.11 & 0.029 \\
\hline Biochar & 1,4 & 1010144.70 & 14.87 & 0.018 \\
\hline Time & 13,52 & 4257786.91 & 66.84 & $<0.001$ \\
\hline Biochar $\times$ Time & 13,52 & 191762.68 & 3.01 & 0.002 \\
\hline Shell slag & 1,4 & 681857.98 & 2.09 & 0.222 \\
\hline Time & 13,52 & 4018988.61 & 58.89 & $<0.001$ \\
\hline Shell slag $\times$ Time & 13,52 & 182597.32 & 2.68 & 0.006 \\
\hline Gypsum slag & 1,4 & 1483139.92 & 31.37 & 0.005 \\
\hline Time & 13,52 & 4045259.60 & 115.47 & $<0.001$ \\
\hline Gypsum slag $\times$ Time & 13,52 & 57447.00 & 1.64 & 0.104 \\
\hline $\begin{array}{lll}\text { Silicate } & \text { and } & \text { calcium } \\
\text { fertilizer } & & \end{array}$ & 1,4 & 1100188.81 & 7.62 & 0.049 \\
\hline Time & 13,52 & 4341463.96 & 109.38 & $<0.001$ \\
\hline $\begin{array}{ll}\text { Silicate } \quad \text { and } & \text { calcium } \\
\text { fertilizer } \times \text { Time } & \end{array}$ & 13,52 & 63784.18 & 1.61 & 0.113 \\
\hline \multicolumn{5}{|l|}{$\mathrm{CH}_{4}$} \\
\hline Steel slag & 1,4 & 412.28 & 8.35 & 0.046 \\
\hline Time & 13,52 & 81.64 & 9.57 & $<0.001$ \\
\hline Steel $\times$ Time & 13,52 & 31.72 & 3.72 & $<0.001$ \\
\hline Biochar & 1,4 & 480.55 & 8.49 & 0.043 \\
\hline Time & 13,52 & 60.32 & 6.35 & $<0.001$ \\
\hline Biochar $\times$ Time & 13,52 & 48.70 & 5.13 & $<0.001$ \\
\hline Shell slag & 1,4 & 425.31 & 9.28 & 0.038 \\
\hline Time & 13,52 & 63.21 & 8.65 & $<0.001$ \\
\hline Shell slag $\times$ Time & 13,52 & 48.03 & 6.57 & $<0.001$ \\
\hline Gypsum slag & 1,4 & 718.25 & 14.70 & 0.019 \\
\hline Time & 13,52 & 60.75 & 8.74 & $<0.001$ \\
\hline Gypsum slag $\times$ Time & 13,52 & 39.73 & 5.71 & $<0.001$ \\
\hline
\end{tabular}




\begin{tabular}{|l|l|l|l|l|}
\hline $\begin{array}{l}\text { Silicate and calcium } \\
\text { fertilizer }\end{array}$ & 1,4 & 220.70 & 4.57 & 0.099 \\
\hline Time calcium & 13,52 & 33.43 & 11.64 & $<0.001$ \\
\hline $\begin{array}{l}\text { Silicate and } \\
\text { fertilizer } \times \text { Time }\end{array}$ & & & 4.23 & $<0.001$ \\
\hline $\mathrm{N}_{2} \mathrm{O}$ & 1,4 & 4189.01 & 1.75 & 0.256 \\
\hline Steel slag & 13,52 & 3700.64 & 1.33 & 0.225 \\
\hline Time & 13,52 & 1752.89 & 0.63 & 0.816 \\
\hline Steel $\times$ Time & 1,4 & 30732.38 & 7.61 & 0.049 \\
\hline Biochar & 13,52 & 7576.81 & 2.47 & 0.011 \\
\hline Time & 13,52 & 3142.42 & 1.02 & 0.444 \\
\hline Biochar $\times$ Time & 1,4 & 15000.62 & 6.27 & 0.066 \\
\hline Shell slag & 13,52 & 974.07 & 1.20 & 0.305 \\
\hline Time & 13,52 & 864.42 & 1.07 & 0.408 \\
\hline Shell slag $\times$ Time & 1,4 & 51808.84 & 2.35 & 0.200 \\
\hline Gypsum slag & 13,52 & 5964.84 & 1.08 & 0.393 \\
\hline Time & 13,52 & 2278.31 & 0.41 & 0.958 \\
\hline Gypsum slag $\times$ Time & 1,4 & 36332.03 & 3.57 & 0.132 \\
\hline $\begin{array}{l}\text { Silicate and calcium } \\
\text { fertilizer }\end{array}$ & 13,52 & 2259.63 & 0.92 & 0.541 \\
\hline Time & 13,52 & 2223.64 & 0.90 & 0.555 \\
\hline $\begin{array}{l}\text { Silicate and calcium } \\
\text { fertilizer } \times \text { Time }\end{array}$ & & & \\
\hline & 1,4 & & \\
\hline
\end{tabular}


14 Table S3. Summary of the RM-ANOVAs for the soil properties for the various amendments.

\begin{tabular}{|c|c|c|c|c|}
\hline & $d f$ & $M S$ & $F$ & $P$ \\
\hline \multicolumn{5}{|l|}{ pH } \\
\hline Steel slag & 1,4 & 1.26 & 31.86 & 0.005 \\
\hline Time & 13,52 & 5.65 & 221.41 & $<0.001$ \\
\hline Steel $\times$ Time & 13,52 & 0.33 & 12.74 & $<0.001$ \\
\hline Biochar & 1,4 & 1.38 & 41.19 & 0.003 \\
\hline Time & 13,52 & 6.08 & 645.02 & $<0.001$ \\
\hline Biochar $\times$ Time & 13,52 & 0.16 & 17.38 & $<0.001$ \\
\hline Shell slag & 1,4 & 1.12 & 28.26 & 0.006 \\
\hline Time & 13,52 & 6.21 & 669.21 & $<0.001$ \\
\hline Shell slag $\times$ Time & 13,52 & 0.14 & 15.08 & $<0.001$ \\
\hline Gypsum slag & 1,4 & 0.16 & 3.78 & 0.124 \\
\hline Time & 13,52 & 5.77 & 194.91 & $<0.001$ \\
\hline Gypsum slag $\times$ Time & 13,52 & 0.10 & 3.36 & 0.001 \\
\hline $\begin{array}{l}\text { Silicate and calcium } \\
\text { fertilizer }\end{array}$ & 1,4 & 11.46 & 213.84 & $<0.001$ \\
\hline Time & 13,52 & 5.80 & 269.79 & $<0.001$ \\
\hline $\begin{array}{l}\text { Silicate and calcium } \\
\text { fertilizer } \times \text { Time }\end{array}$ & 13,52 & 1.24 & 57.55 & $<0.001$ \\
\hline \multicolumn{5}{|l|}{ Eh } \\
\hline Steel slag & 1,4 & 2003.44 & 95.74 & 0.001 \\
\hline Time & 13,52 & 9145.69 & 89.72 & $<0.001$ \\
\hline Steel $\times$ Time & 13,52 & 475.57 & 4.67 & $<0.001$ \\
\hline Biochar & 1,4 & 3784.17 & 261.73 & $<0.001$ \\
\hline Time & 13,52 & 8332.97 & 148.62 & $<0.001$ \\
\hline Biochar $\times$ Time & 13,52 & 606.72 & 10.82 & $<0.001$ \\
\hline Shell slag & 1,4 & 3971.69 & 292.15 & $<0.001$ \\
\hline Time & 13,52 & 8856.19 & 157.64 & $<0.001$ \\
\hline Shell slag $\times$ Time & 13,52 & 639.82 & 11.39 & $<0.001$ \\
\hline Gypsum slag & 1,4 & 5982.61 & 22.97 & 0.009 \\
\hline Time & 13,52 & 9472.70 & 40.39 & $<0.001$ \\
\hline Gypsum slag $\times$ Time & 13,52 & 1663.69 & 7.09 & $<0.001$ \\
\hline
\end{tabular}




\begin{tabular}{|c|c|c|c|c|}
\hline $\begin{array}{l}\text { Silicate and calcium } \\
\text { fertilizer }\end{array}$ & 1,4 & 3140.30 & 46.36 & 0.002 \\
\hline Time & 13,52 & 6395.00 & 74.14 & $<0.001$ \\
\hline $\begin{array}{l}\text { Silicate and calcium } \\
\text { fertilizer } \times \text { Time }\end{array}$ & 13,52 & 3093.60 & 35.87 & $<0.001$ \\
\hline \multicolumn{5}{|l|}{ Temperature } \\
\hline Steel slag & 1,4 & 0.03 & 1.15 & 0.344 \\
\hline Time & 13,52 & 61.60 & 3872.83 & $<0.001$ \\
\hline Steel $\times$ Time & 13,52 & 0.01 & 0.57 & 0.869 \\
\hline Biochar & 1,4 & 0.09 & 5.30 & 0.083 \\
\hline Time & 13,52 & 62.78 & 3615.67 & $<0.001$ \\
\hline Biochar $\times$ Time & 13,52 & 0.02 & 1.34 & 0.219 \\
\hline Shell slag & 1,4 & 0.06 & 2.47 & 0.191 \\
\hline Time & 13,52 & 62.72 & 1860.06 & $<0.001$ \\
\hline Shell slag $\times$ Time & 13,52 & 0.07 & 2.09 & 0.031 \\
\hline Gypsum slag & 1,4 & 0.86 & 32.40 & 0.005 \\
\hline Time & 13,52 & 64.15 & 2253.27 & $<0.001$ \\
\hline Gypsum slag $\times$ Time & 13,52 & 0.17 & 5.98 & $<0.001$ \\
\hline $\begin{array}{l}\text { Silicate and calcium } \\
\text { fertilizer }\end{array}$ & 1,4 & 0.53 & 4.04 & 0.115 \\
\hline Time & 13,52 & 62.06 & 2486.82 & $<0.001$ \\
\hline $\begin{array}{l}\text { Silicate and calcium } \\
\text { fertilizer } \times \text { Time }\end{array}$ & 13,52 & 0.17 & 6.93 & $<0.001$ \\
\hline \multicolumn{5}{|l|}{ Salinity } \\
\hline Steel slag & 1,4 & 0.43 & 14.21 & 0.020 \\
\hline Time & 13,52 & 0.20 & 35.64 & $<0.001$ \\
\hline Steel $\times$ Time & 13,52 & 0.01 & 1.10 & 0.377 \\
\hline Biochar & 1,4 & 0.25 & 2.99 & 0.159 \\
\hline Time & 13,52 & 0.18 & 13.08 & $<0.001$ \\
\hline Biochar $\times$ Time & 13,52 & 0.01 & 0.75 & 0.705 \\
\hline Shell slag & 1,4 & 0.33 & 13.96 & 0.020 \\
\hline Time & 13,52 & 0.20 & 8.72 & $<0.001$ \\
\hline Shell slag $\times$ Time & 13,52 & 0.02 & 0.80 & 0.662 \\
\hline Gypsum slag & 1,4 & 2.42 & 68.20 & 0.001 \\
\hline
\end{tabular}




\begin{tabular}{|c|c|c|c|c|}
\hline Time & 13,52 & 0.26 & 16.59 & $<0.001$ \\
\hline Gypsum slag $\times$ Time & 13,52 & 0.04 & 2.59 & 0.008 \\
\hline $\begin{array}{l}\text { Silicate and calcium } \\
\text { fertilizer }\end{array}$ & 1,4 & 1.24 & 76.53 & 0.001 \\
\hline Time & 13,52 & 0.29 & 38.69 & $<0.001$ \\
\hline $\begin{array}{l}\text { Silicate and calcium } \\
\text { fertilizer } \times \text { Time }\end{array}$ & 13,52 & 0.03 & 3.55 & 0.001 \\
\hline \multicolumn{5}{|l|}{ Water content } \\
\hline Steel slag & 1,4 & 444.36 & 23.63 & 0.008 \\
\hline Time & 13,52 & 649.64 & 194.83 & $<0.001$ \\
\hline Steel $\times$ Time & 13,52 & 15.67 & 4.70 & $<0.001$ \\
\hline Biochar & 1,4 & 127.65 & 12.32 & 0.025 \\
\hline Time & 13,52 & 526.48 & 108.79 & $<0.001$ \\
\hline Biochar $\times$ Time & 13,52 & 9.35 & 1.93 & 0.048 \\
\hline Shell slag & 1,4 & 57.75 & 4.88 & 0.092 \\
\hline Time & 13,52 & 636.61 & 89.86 & $<0.001$ \\
\hline Shell slag $\times$ Time & 13,52 & 13.35 & 1.88 & 0.054 \\
\hline Gypsum slag & 1,4 & 7495.74 & 561.03 & $<0.001$ \\
\hline Time & 13,52 & 708.13 & 131.41 & $<0.001$ \\
\hline Gypsum slag $\times$ Time & 13,52 & 13.72 & 2.55 & 0.009 \\
\hline $\begin{array}{l}\text { Silicate and calcium } \\
\text { fertilizer }\end{array}$ & 1,4 & 1087.20 & 84.55 & 0.001 \\
\hline Time & 13,52 & 753.49 & 132.26 & $<0.001$ \\
\hline $\begin{array}{l}\text { Silicate and calcium } \\
\text { fertilizer } \times \text { Time }\end{array}$ & 13,52 & 46.70 & 8.20 & $<0.001$ \\
\hline \multicolumn{5}{|l|}{$\mathrm{Fe}^{2+}$ concentration } \\
\hline Steel slag & 1,4 & 5.95 & 124.59 & $<0.001$ \\
\hline Time & 13,52 & 6.32 & 30.68 & $<0.001$ \\
\hline Steel $\times$ Time & 13,52 & 0.53 & 2.56 & 0.008 \\
\hline Biochar & 1,4 & 4.03 & 17.71 & 0.014 \\
\hline Time & 13,52 & 5.09 & 20.85 & $<0.001$ \\
\hline Biochar $\times$ Time & 13,52 & 0.25 & 1.04 & 0.433 \\
\hline Shell slag & 1,4 & 0.22 & 0.33 & 0.598 \\
\hline Time & 13,52 & 4.09 & 11.32 & $<0.001$ \\
\hline
\end{tabular}




\begin{tabular}{|c|c|c|c|c|}
\hline Shell slag $\times$ Time & 13,52 & 0.79 & 2.18 & 0.024 \\
\hline Gypsum slag & 1,4 & $<0.001$ & 0.01 & 0.934 \\
\hline Time & 13,52 & 5.20 & 29.03 & $<0.001$ \\
\hline Gypsum slag $\times$ Time & 13,52 & 0.41 & 2.28 & 0.018 \\
\hline $\begin{array}{l}\text { Silicate and calcium } \\
\text { fertilizer }\end{array}$ & 1,4 & 4.23 & 112.25 & $<0.001$ \\
\hline Time & 13,52 & 4.74 & 24.79 & $<0.001$ \\
\hline $\begin{array}{l}\text { Silicate and calcium } \\
\text { fertilizer } \times \text { Time }\end{array}$ & 13,52 & 0.74 & 3.89 & $<0.001$ \\
\hline \multicolumn{5}{|l|}{$\mathrm{Fe}^{3+}$ concentration } \\
\hline Steel slag & 1,4 & 2.36 & 1.11 & 0.352 \\
\hline Time & 13,52 & 22.12 & 24.77 & $<0.001$ \\
\hline Steel $\times$ Time & 13,52 & 1.08 & 1.21 & 0.297 \\
\hline Biochar & 1,4 & 46.95 & 48.63 & 0.002 \\
\hline Time & 13,52 & 31.70 & 19.71 & $<0.001$ \\
\hline Biochar $\times$ Time & 13,52 & 2.19 & 1.36 & 0.211 \\
\hline Shell slag & 1,4 & 64.06 & 9.63 & 0.036 \\
\hline Time & 13,52 & 22.63 & 8.61 & $<0.001$ \\
\hline Shell slag $\times$ Time & 13,52 & 4.45 & 1.69 & 0.091 \\
\hline Gypsum slag & 1,4 & 15.13 & 47.39 & 0.002 \\
\hline Time & 13,52 & 21.32 & 39.06 & $<0.001$ \\
\hline Gypsum slag $\times$ Time & 13,52 & 1.54 & 2.82 & 0.004 \\
\hline $\begin{array}{l}\text { Silicate and calcium } \\
\text { fertilizer }\end{array}$ & 1,4 & 23.11 & 31.57 & 0.005 \\
\hline Time & 13,52 & 20.93 & 26.48 & $<0.001$ \\
\hline $\begin{array}{l}\text { Silicate and calcium } \\
\text { fertilizer } \times \text { Time }\end{array}$ & 13,52 & 1.28 & 1.62 & 0.111 \\
\hline \multicolumn{5}{|l|}{ Total Fe concentration } \\
\hline Steel slag & 1,4 & 15.79 & 6.84 & 0.059 \\
\hline Time & 13,52 & 46.32 & 37.43 & $<0.001$ \\
\hline Steel $\times$ Time & 13,52 & 1.86 & 1.51 & 0.147 \\
\hline Biochar & 1,4 & 78.49 & 89.19 & 0.001 \\
\hline Time & 13,52 & 56.65 & 26.09 & $<0.001$ \\
\hline Biochar $\times$ Time & 13,52 & 3.40 & 1.57 & 0.126 \\
\hline
\end{tabular}




\begin{tabular}{|c|c|c|c|c|}
\hline Shell slag & 1,4 & 71.80 & 6.49 & 0.063 \\
\hline Time & 13,52 & 43.83 & 11.11 & $<0.001$ \\
\hline Shell slag $\times$ Time & 13,52 & 7.40 & 1.87 & 0.056 \\
\hline Gypsum slag & 1,4 & 14.92 & 53.83 & 0.002 \\
\hline Time & 13,52 & 45.19 & 69.93 & $<0.001$ \\
\hline Gypsum slag $\times$ Time & 13,52 & 1.69 & 2.62 & 0.007 \\
\hline $\begin{array}{l}\text { Silicate and calcium } \\
\text { fertilizer }\end{array}$ & 1,4 & 47.10 & 56.19 & 0.002 \\
\hline Time & 13,52 & 42.78 & 37.73 & $<0.001$ \\
\hline $\begin{array}{l}\text { Silicate and calcium } \\
\text { fertilizer } \times \text { Time }\end{array}$ & 13,52 & 1.75 & 1.55 & 0.133 \\
\hline
\end{tabular}

15 
Table S4. Correlations between the soil properties and the greenhouse-gas emissions.

\begin{tabular}{|c|c|c|c|c|c|c|c|c|}
\hline $\mathrm{CO}_{2}$ & $\mathrm{pH}$ & Eh & Temperature & Salinity & Water content & $\mathrm{Fe}^{2+}$ & $\mathrm{Fe}^{3+}$ & Total Fe \\
\hline Control & $-0.28 *$ & 0.148 & $0.815 * *$ & 0.043 & $0.280^{*}$ & $0.353^{*}$ & 0.16 & 0.239 \\
\hline Steel slag & -0.176 & 0.208 & $0.867 * *$ & 0.038 & $0.280^{*}$ & 0.241 & 0.122 & 0.18 \\
\hline Biochar & $-0.357 * *$ & $0.337^{*}$ & $0.807 * *$ & -0.179 & $0.278^{*}$ & 0.218 & -0.05 & 0.025 \\
\hline Shell slag & $-0.306^{*}$ & $0.287^{*}$ & $0.883 * *$ & -0.185 & 0.027 & 0.081 & 0.005 & 0.027 \\
\hline Gypsum slag & $-0.327 *$ & $0.399 * *$ & $0.832 * *$ & 0.1 & $0.275^{*}$ & 0.217 & 0.11 & 0.155 \\
\hline $\begin{array}{l}\text { Silicate and calcium } \\
\text { fertilizer }\end{array}$ & $-0.632 * *$ & $0.301^{*}$ & $0.814 * *$ & 0.17 & $0.461 * *$ & 0.161 & 0.19 & 0.19 \\
\hline \multicolumn{9}{|l|}{$\mathrm{CH}_{4}$} \\
\hline Control & $0.317^{*}$ & -0.235 & $-0.47 * *$ & $0.423 * *$ & $0.277^{*}$ & -0.235 & -0.189 & -0.222 \\
\hline Steel slag & 0.244 & -0.23 & -0.114 & $0.652 * *$ & $0.401^{* *}$ & -0.09 & -0.146 & -0.136 \\
\hline Biochar & -0.045 & -0.001 & -0.06 & $0.528 * *$ & $0.385 * *$ & -0.014 & -0.018 & -0.018 \\
\hline Shell slag & $0.288^{*}$ & -0.149 & -0.015 & $0.309^{*}$ & $0.601 * *$ & $0.286^{*}$ & 0.208 & 0.238 \\
\hline Gypsum slag & $0.332 *$ & -0.216 & $-0.262 *$ & $0.270^{*}$ & $0.434 * *$ & $0.439 * *$ & 0.116 & 0.243 \\
\hline $\begin{array}{l}\text { Silicate and calcium } \\
\text { fertilizer }\end{array}$ & $0.370 * *$ & -0.074 & -0.166 & $0.527 * *$ & $0.669 * *$ & $0.259^{*}$ & $0.499 * *$ & $0.439 * *$ \\
\hline \multicolumn{9}{|l|}{$\mathbf{N}_{2} \mathbf{O}$} \\
\hline Control & 0.14 & -0.148 & -0.185 & 0.199 & 0.113 & -0.142 & -0.094 & -0.118 \\
\hline Steel slag & 0.152 & -0.226 & -0.097 & 0.021 & 0.012 & 0.172 & $0.299 *$ & $0.273^{*}$ \\
\hline
\end{tabular}




\begin{tabular}{|c|c|c|c|c|c|c|c|c|}
\hline Biochar & 0.18 & -0.254 & $-0.43 * *$ & $0.464 * *$ & 0.077 & -0.035 & 0.151 & 0.106 \\
\hline Shell slag & 0.189 & -0.088 & -0.234 & -0.078 & -0.192 & -0.021 & 0.028 & 0.015 \\
\hline Gypsum slag & -0.128 & 0.18 & 0.096 & -0.177 & -0.06 & -0.102 & 0.011 & -0.031 \\
\hline $\begin{array}{l}\text { Silicate and calcium } \\
\text { fertilizer }\end{array}$ & -0.022 & 0.172 & -0.029 & -0.202 & $-0.323 *$ & $-0.326^{*}$ & $-0.424 * *$ & $-0.412 * *$ \\
\hline
\end{tabular}

*, significant at the 0.05 level; **, significant at the 0.01 level 

Mahalanobis distances. Bold type indicates a significant effect of the variable in the model $(P<0.05)$

Table S5. Test statistics for squared Mahalanobis distances among the plots receiving the fertilization treatments with soil $\mathrm{pH}$, Eh, temperature, salinity, water content, $\mathrm{Fe}^{2+}$ concentration, $\mathrm{Fe}^{3+}$ concentration and $\mathrm{CO}_{2}, \mathrm{CH}_{4}$ and $\mathrm{N}_{2} \mathrm{O}$ emissions during the sampling period as independent continuous variables and sampling time as the categorical independent variable. Sq. Mah. $=$ Squared

\begin{tabular}{|c|c|c|c|c|c|}
\hline & Steel slag & Biochar & Shell slag & Gypsum slag & $\begin{array}{l}\text { Silicate plus } \\
\text { calcium fertilizer }\end{array}$ \\
\hline Control & $\begin{array}{l}\text { Sq. Mah. }=7.68 \\
P<0.0001\end{array}$ & $\begin{array}{l}\text { Sq. Mah. }=7.43 \\
P<0.0001\end{array}$ & $\begin{array}{l}\text { Sq. Mah. }=6.65 \\
P<0.0001\end{array}$ & $\begin{array}{l}\text { Sq. Mah. }=47.0 \\
P<0.0001\end{array}$ & $\begin{array}{l}\text { Sq. Mah. }=17.9 \\
P<0.0001\end{array}$ \\
\hline Steel slag & & $\begin{array}{l}\text { Sq. Mah. }=1.70 \\
P=0.11\end{array}$ & $\begin{array}{l}\text { Sq. Mah. }=3.59 \\
P<0.0001\end{array}$ & $\begin{array}{l}\text { Sq. Mah. }=23.1 \\
P<0.0001\end{array}$ & $\begin{array}{l}\text { Sq. Mah. }=4.12 \\
P<0.0001\end{array}$ \\
\hline Biochar & & & $\begin{array}{l}\text { Sq. Mah. }= \\
0.660 P=0.96\end{array}$ & $\begin{array}{l}\text { Sq. Mah. }=27.7 \\
P<0.0001\end{array}$ & $\begin{array}{l}\text { Sq. Mah. }=5.51 \\
P<0.0001\end{array}$ \\
\hline Shell slag & & & & $\begin{array}{l}3 \text { Sq. Mah. }=0.746 \\
P<0.0001\end{array}$ & $\begin{array}{l}\text { Sq. } \text { Mah. }=7.65 \\
P<0.0001\end{array}$ \\
\hline Gypsum slag & & & & & $\begin{array}{l}\text { Sq. Mah. }=15.9 \\
P<0.0001\end{array}$ \\
\hline
\end{tabular}


Table S6. Statistical significance of the independent variables in the general discriminant analysis with the fertilization treatments as the dependent categorical grouping variable. Bold type indicates significant differences $(P<0.05)$.

\begin{tabular}{|l|l|l|}
\hline Variable & $\begin{array}{c}\text { Wilks' lambda } \\
\text { Value }\end{array}$ & $P$ \\
\hline $\mathbf{p H}$ & $\mathbf{0 . 7 2 6}$ & $<\mathbf{0 . 0 0 0 0 1}$ \\
\hline Eh & $\mathbf{0 . 9 4 6}$ & $\mathbf{0 . 0 2 7}$ \\
\hline Temperature & 0.973 & 0.29 \\
\hline Salinity & $\mathbf{0 . 9 1 4}$ & $\mathbf{0 . 0 0 1 1}$ \\
\hline Water content $^{\mathbf{0 . 3 3 6}}$ & $<\mathbf{0 . 0 0 0 0 1}$ \\
\hline Fe $^{2+}$ & $\mathbf{0 . 8 4 7}$ & $<\mathbf{0 . 0 0 0 0 1}$ \\
\hline Fe $^{3+}$ & $\mathbf{0 . 8 4 4}$ & $<\mathbf{0 . 0 0 0 0 1}$ \\
\hline $\begin{array}{l}\mathbf{C H} \\
\text { emissions }\end{array}$ & $\mathbf{0 . 8 2 3}$ & $<\mathbf{0 . 0 0 0 0 1}$ \\
\hline $\begin{array}{l}\mathbf{C O} \\
\text { emissions }\end{array}$ & $\mathbf{0 . 9 3 4}$ & $\mathbf{0 . 0 0 9 0}$ \\
\hline $\begin{array}{l}\mathbf{N}_{2} \mathbf{O} \\
\text { emissions }\end{array}$ & $\mathbf{0 . 9 5 1}$ & $\mathbf{0 . 0 4 7}$ \\
\hline Time & $\mathbf{0 . 2 6 3}$ & $<\mathbf{0 . 0 0 0 0 1}$ \\
\hline
\end{tabular}


61

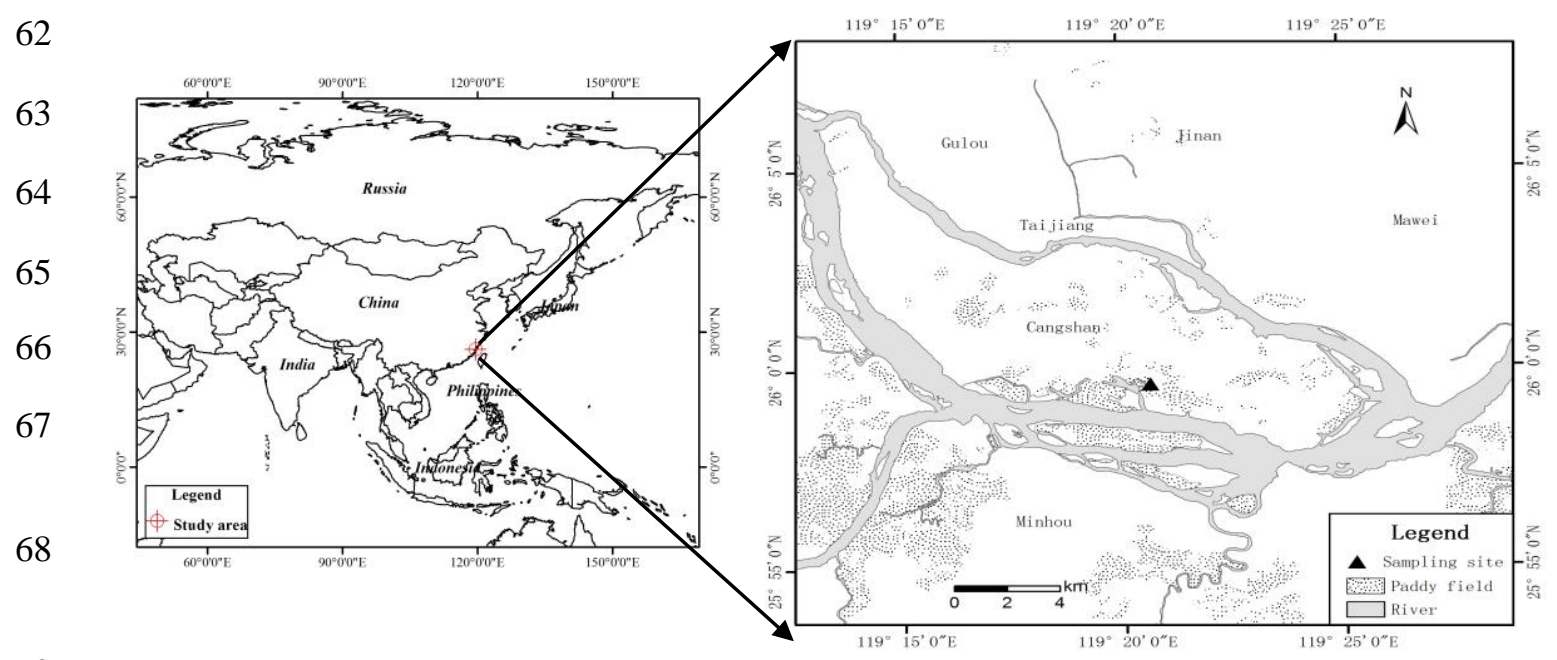

69

70 Figure S1. The location of the study area and sampling sites $(\boldsymbol{\Delta})$ in Fujian Province, 71 southeastern China.

72

73

74

75

76

77

78

79 

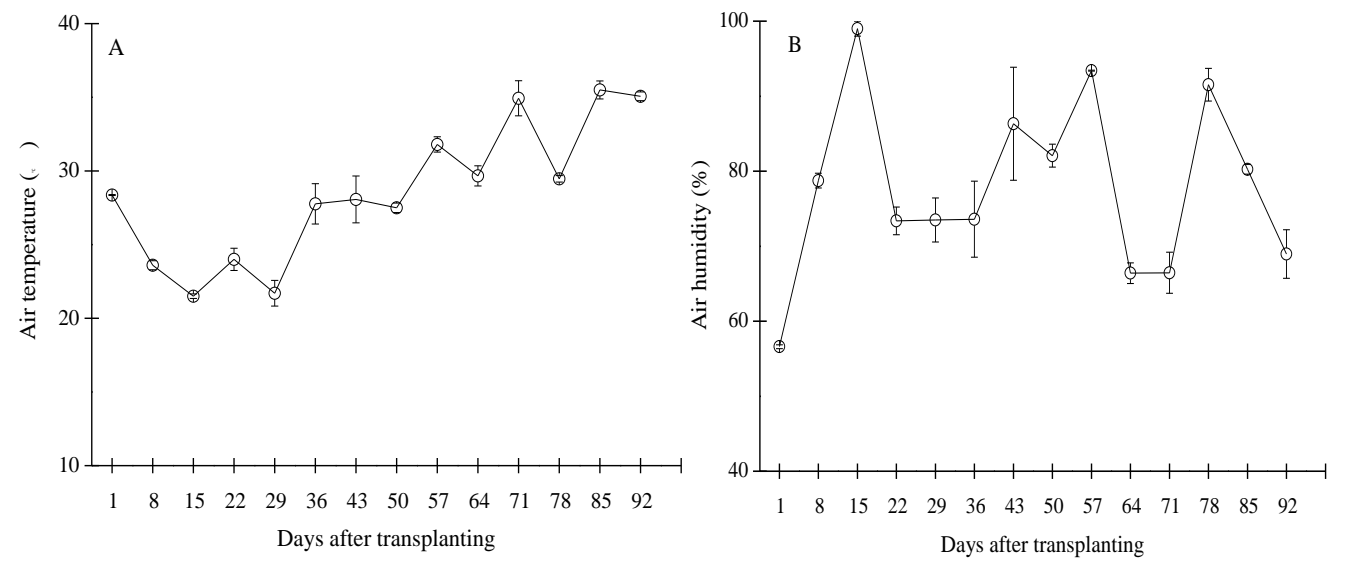

80

81

82 Figure S2. Temporal variation of air temperature (A) and humidity (B) in the study site.

83

84

85

86

87

88

89

90

91

92

93

94

95

96 


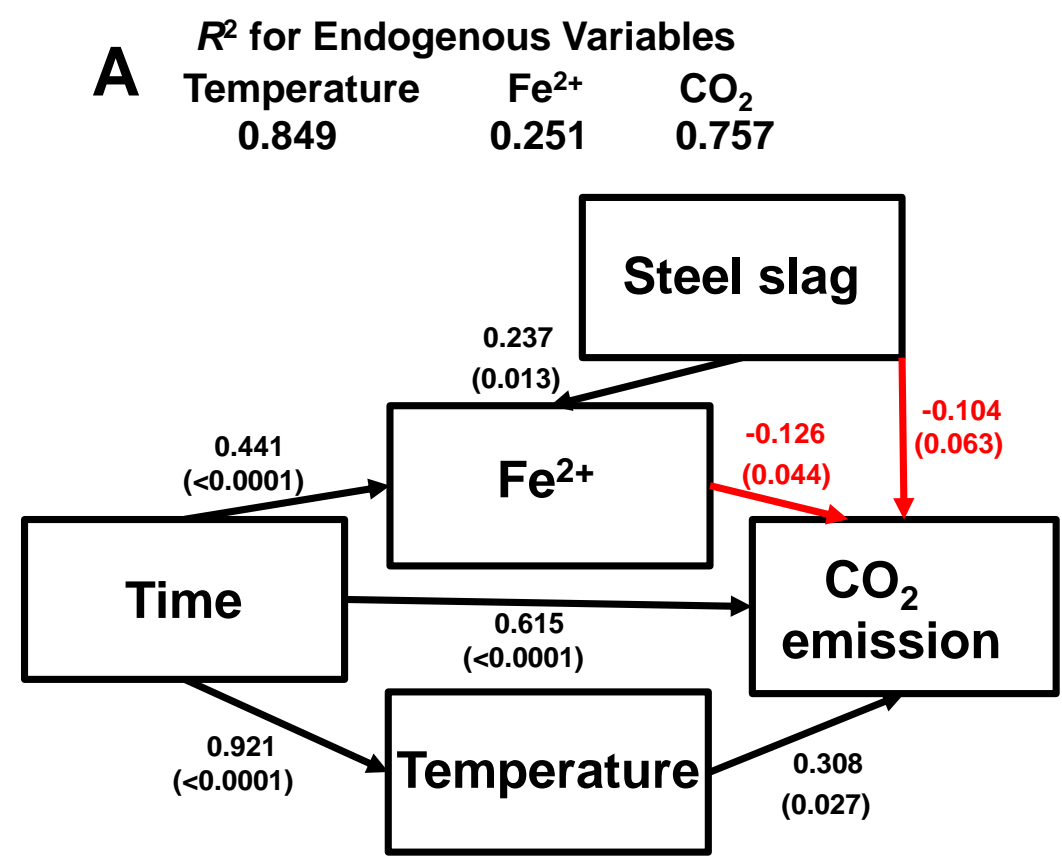

\section{B $\quad R^{2}$ for Endogenous Variables \\ Salinity Temperature $\mathrm{CH}_{4}$
0.136
0.849
0.355

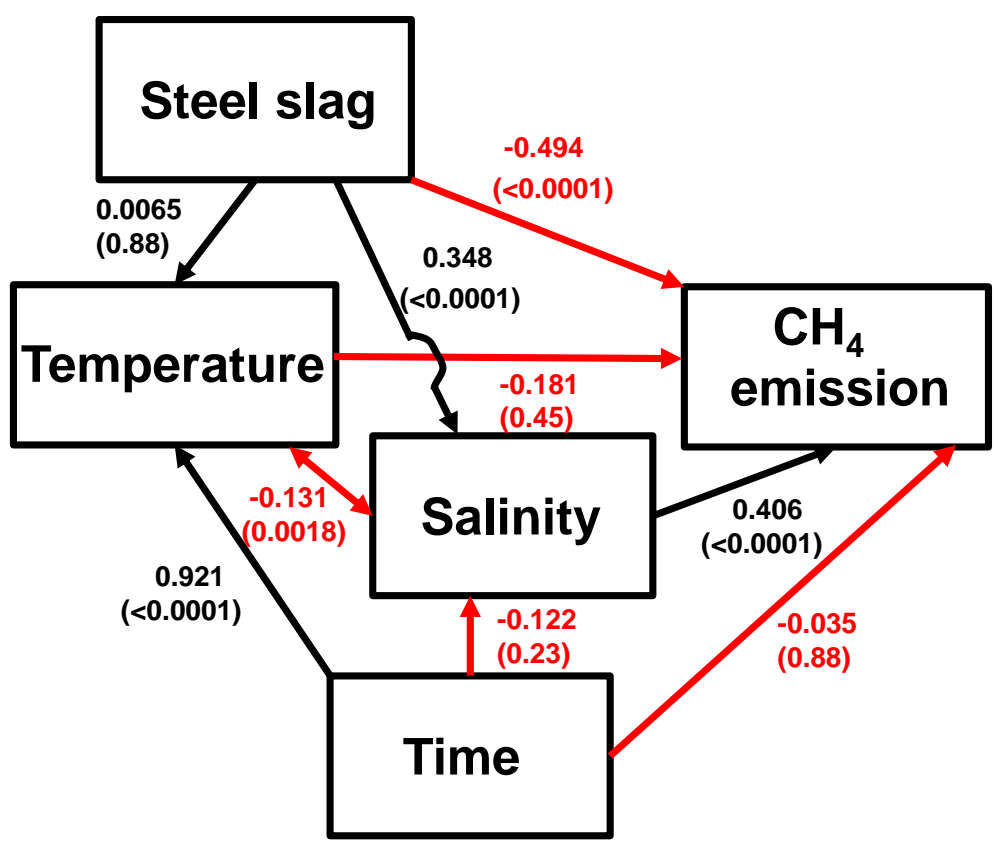

98 Fig S3. Diagrams of the structural equation models comparing plots amended with steel 99 slag versus the control plots that best explained the maximum variance of the soil $\mathrm{CO}_{2}$

100 (A) and $\mathrm{CH}_{4}(\mathrm{~B})$ emissions and implying indirect effects from the amendment on the 101 soil variables. Black and red arrows indicate positive and negative relationships, 102 respectively. 

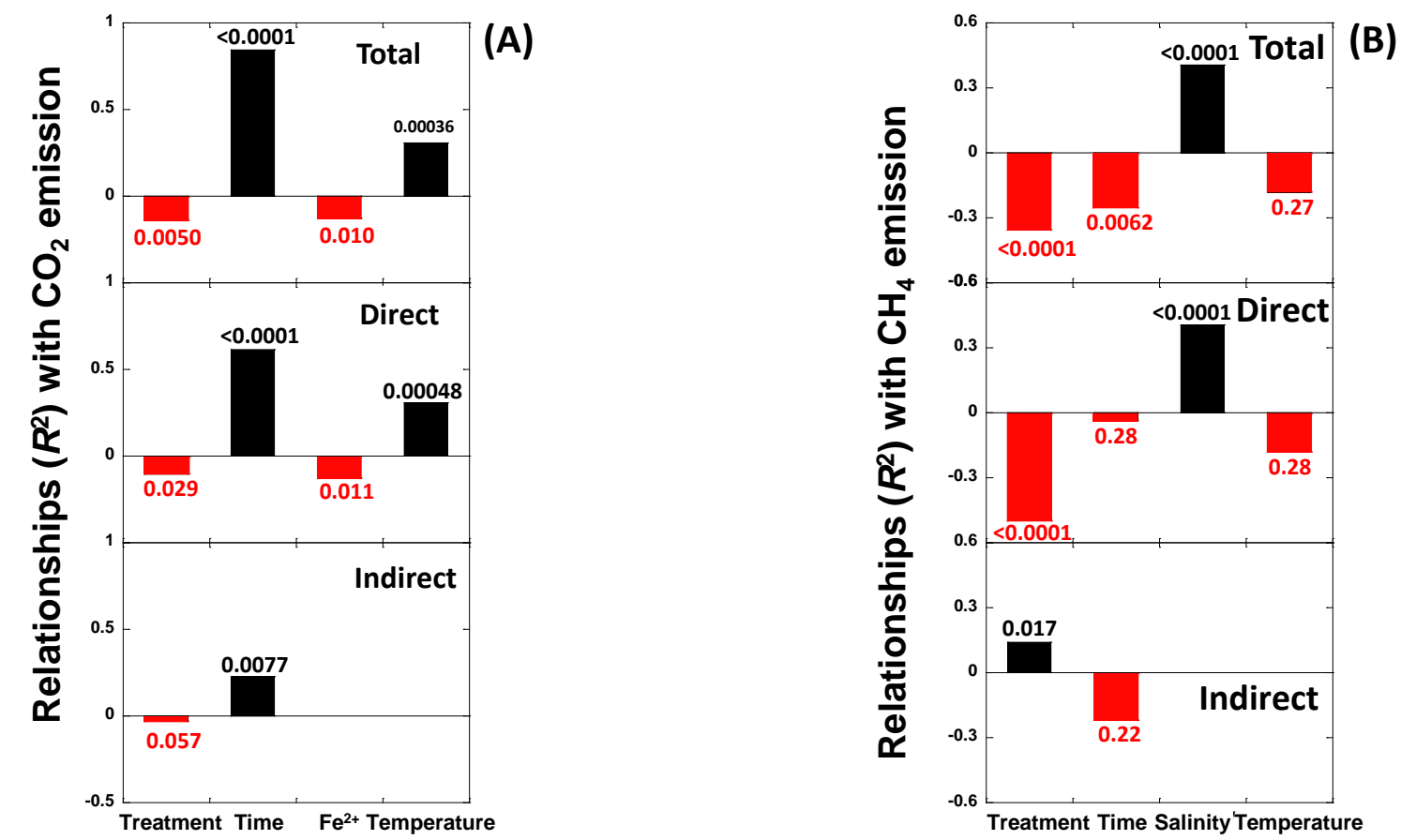

Figure S4. Total, direct and indirect effects of exogenous variables (soil variables) of the SEM models of the plots amended with steel slag versus the control plots that best explained the maximum variance of the soil $\mathrm{CO}_{2}(\mathrm{~A})$ and $\mathrm{CH}_{4}(\mathrm{~B})$ emissions. Black and red columns indicate positive and negative relationships, respectively. 
$R^{2}$ for Endogenous Variables Temperature $\quad \mathrm{CO}_{2}$

0.846

(A)
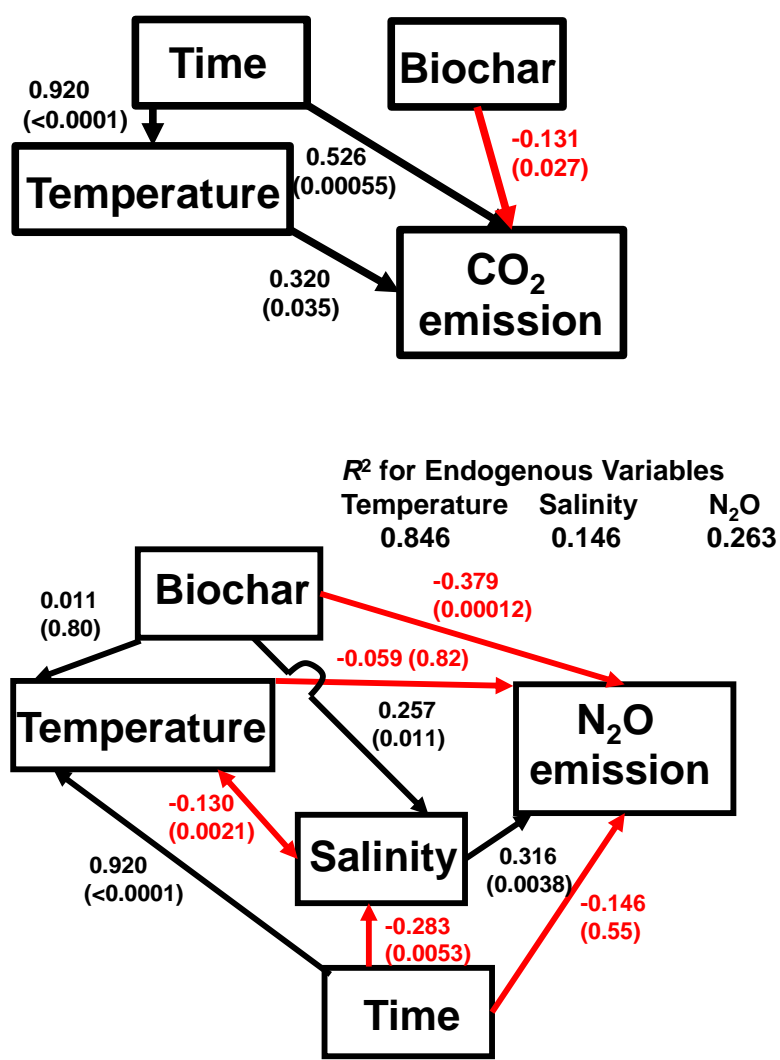

(C)

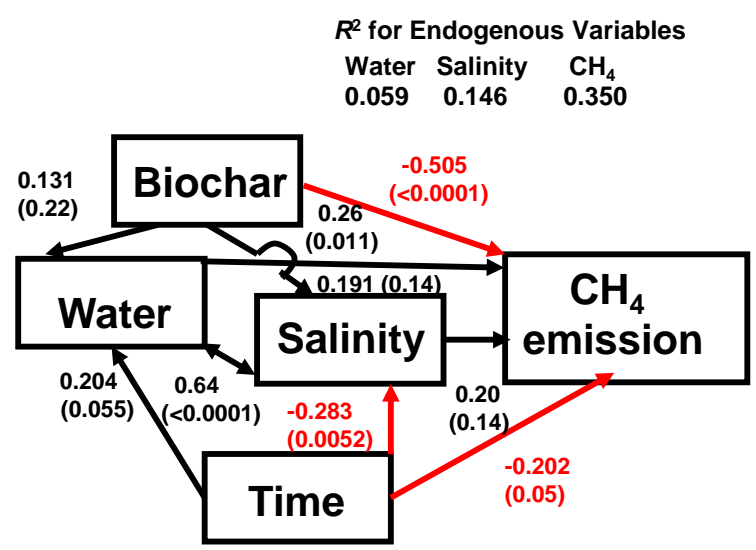

(B)

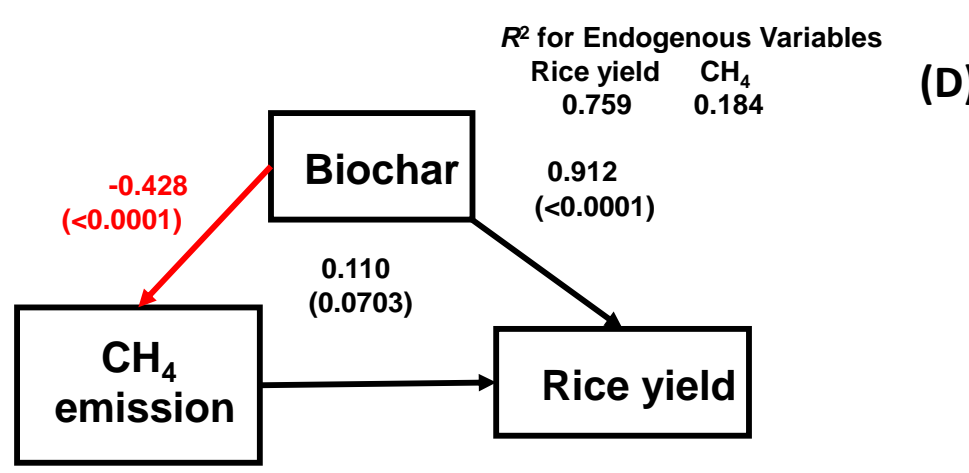

Figure S5. Diagrams of the structural equation models comparing plots amended with biochar versus the control plots that best explained the maximum variance of the soil $\mathrm{CO}_{2}(\mathrm{~A}), \mathrm{CH}_{4}(\mathrm{~B})$ and $\mathrm{N}_{2} \mathrm{O}(\mathrm{C})$ emissions and rice yields (D) and implying indirect effects from the amendment on the soil variables. Black and red arrows indicate positive and negative relationships, respectively. 

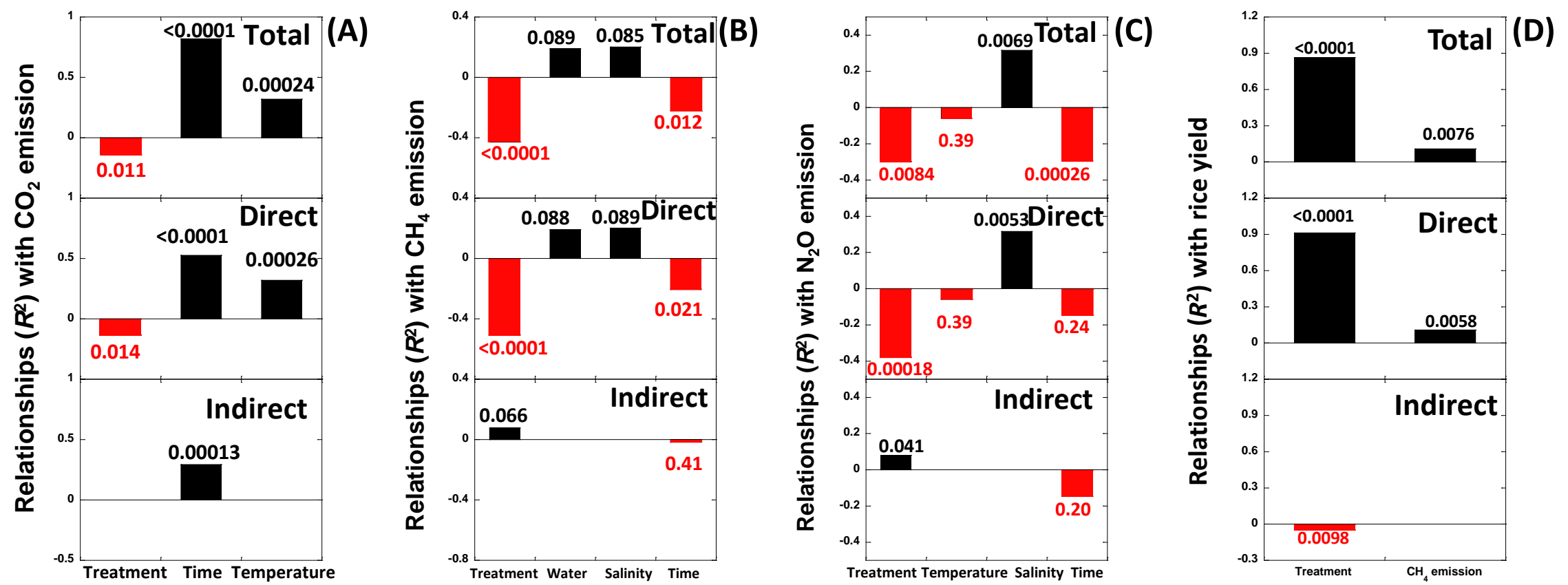

Figure S6. Total, direct and indirect effects of exogenous variables (soil variables) of the SEM models of plots amended with biochar versus the control plots that best explained the maximum variance of the soil $\mathrm{CO}_{2}(\mathrm{~A}), \mathrm{CH}_{4}(\mathrm{~B})$ and $\mathrm{N}_{2} \mathrm{O}(\mathrm{C})$ emissions and rice yields (D). Black and red columns indicate positive and negative relationships, respectively. 


\section{$R^{2}$ for Endogenous Variables Salinity $\quad \mathrm{CH}_{4}$ $0.146 \quad 0.333$}

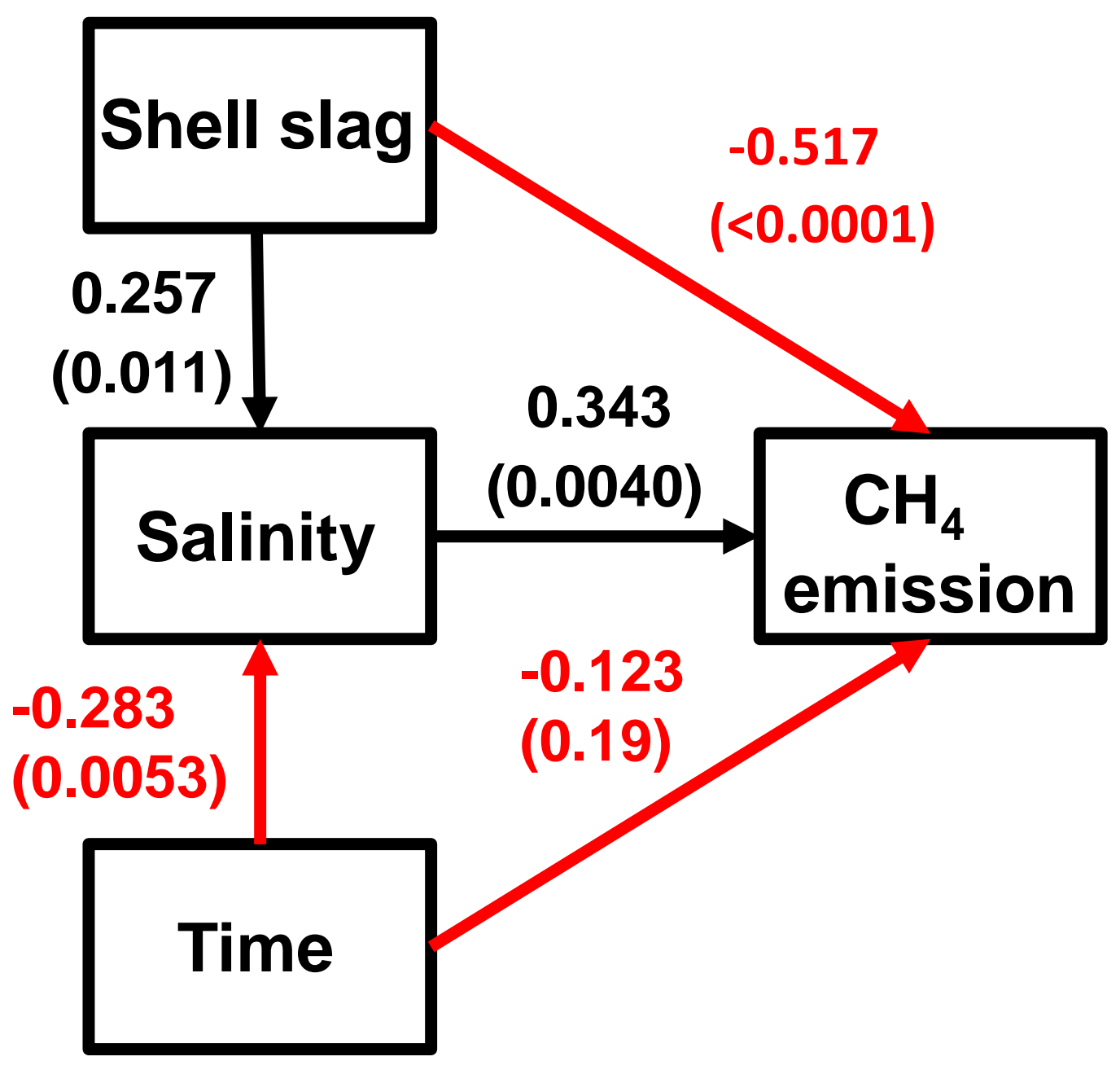

123 Figure S7. Diagrams of the structural equation models comparing plots amended with shell slag versus the control plots that best explained the maximum variance of the soil $\mathrm{CH}_{4}$ emissions and implying indirect effects from the effects of the amendment on the soil variables. Black and red arrows indicate positive and negative relationships, respectively. 


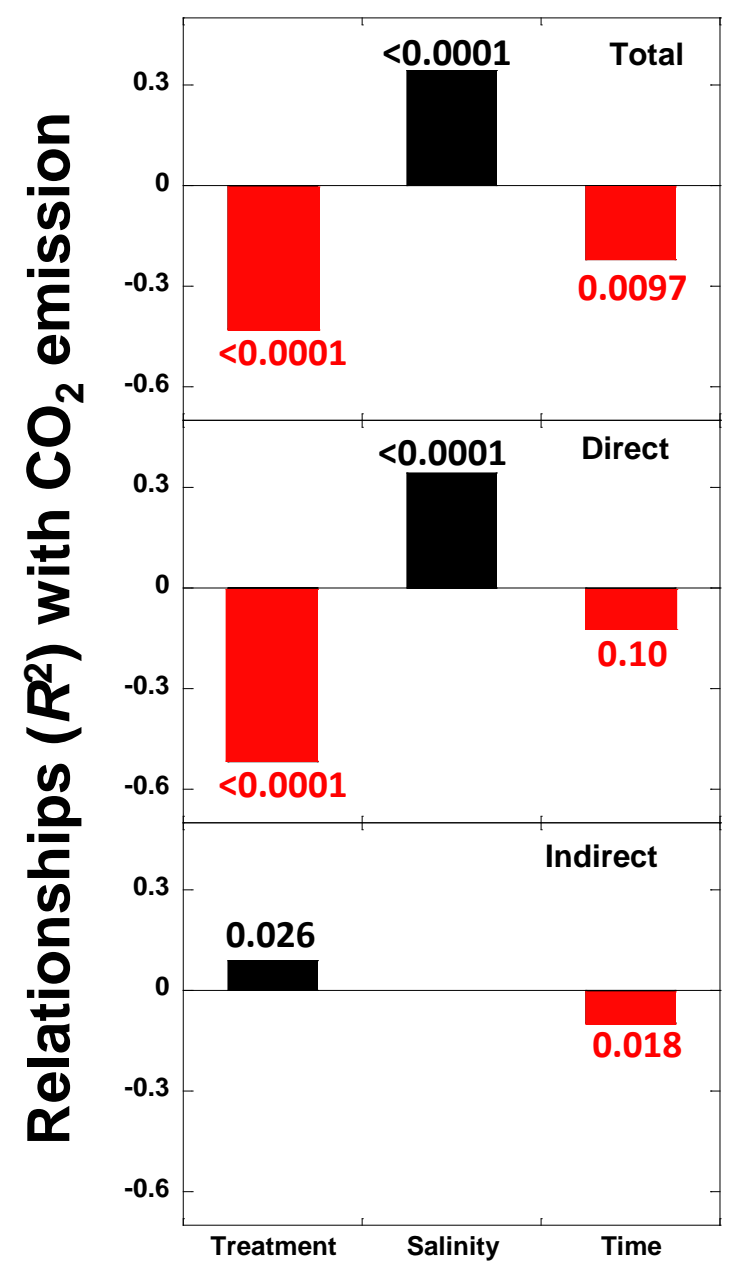

134 Figure S8. Total, direct and indirect effects of exogenous variables (soil variables) of 135 the SEM models comparing plots amended with shell slag versus the control plots that best explained the maximum variance of the soil $\mathrm{CH}_{4}$ emissions. Black and red columns indicate positive and negative relationships, respectively. 


\section{$R^{2}$ for Endogenous Variables \\ A $\quad \begin{array}{ll}\text { Water } & \mathrm{CO}_{2} \\ 0.455 & 0.743\end{array}$}

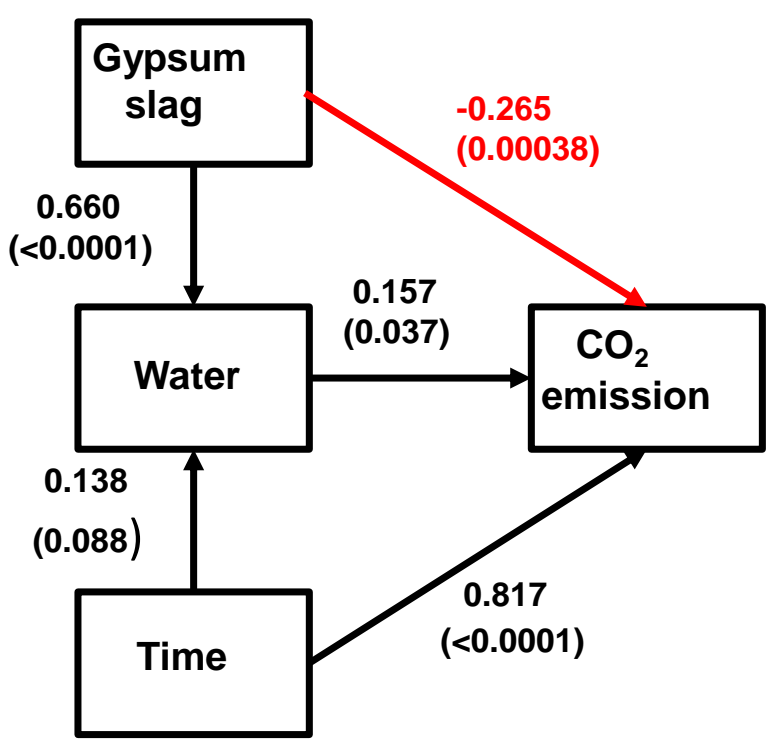
B $R^{2}$ for Endogenous Variables

$\begin{array}{ll}\text { Water } & \mathrm{CH}_{4} \\ 0.455 & 0.416\end{array}$

147 Figure S9. Diagrams of the structural equation models comparing plots amended with gypsum slag versus the control plots that best explained the maximum variance of the soil $\mathrm{CO}_{2}(\mathrm{~A})$ and $\mathrm{CH}_{4}(\mathrm{~B})$ emissions and implying indirect effects from the effects of the amendment on the soil variables. Black and red arrows indicate positive and negative relationships, respectively. 

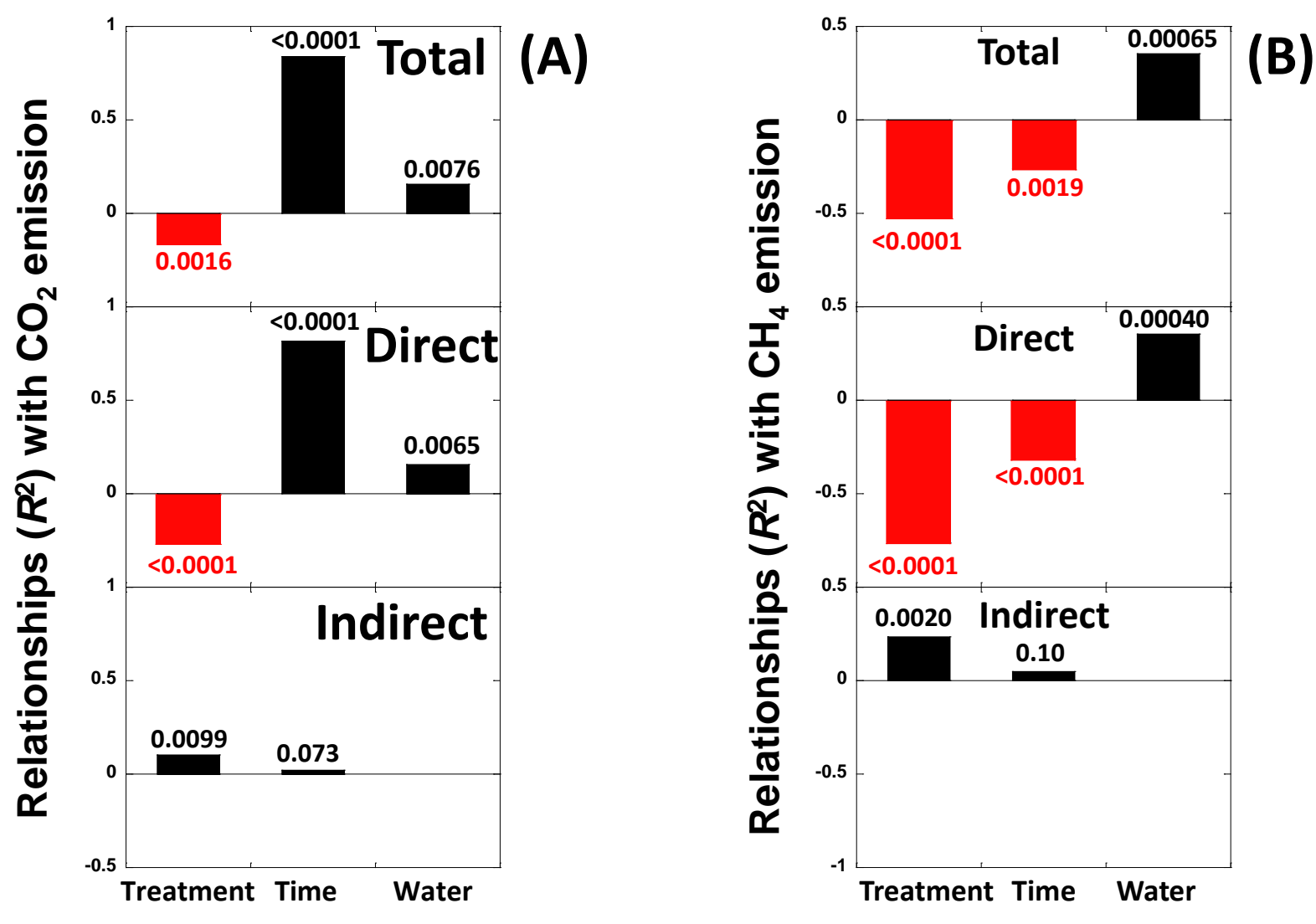

Figure S10. Total, direct and indirect effects of exogenous variables (soil variables) of the SEM models comparing plots amended with gypsum slag versus the control plots that best explained the maximum variance of the soil $\mathrm{CO}_{2}(\mathrm{~A})$ and $\mathrm{CH}_{4}(\mathrm{~B})$ emissions. Black and red arrows indicate positive and negative relationships, respectively. 


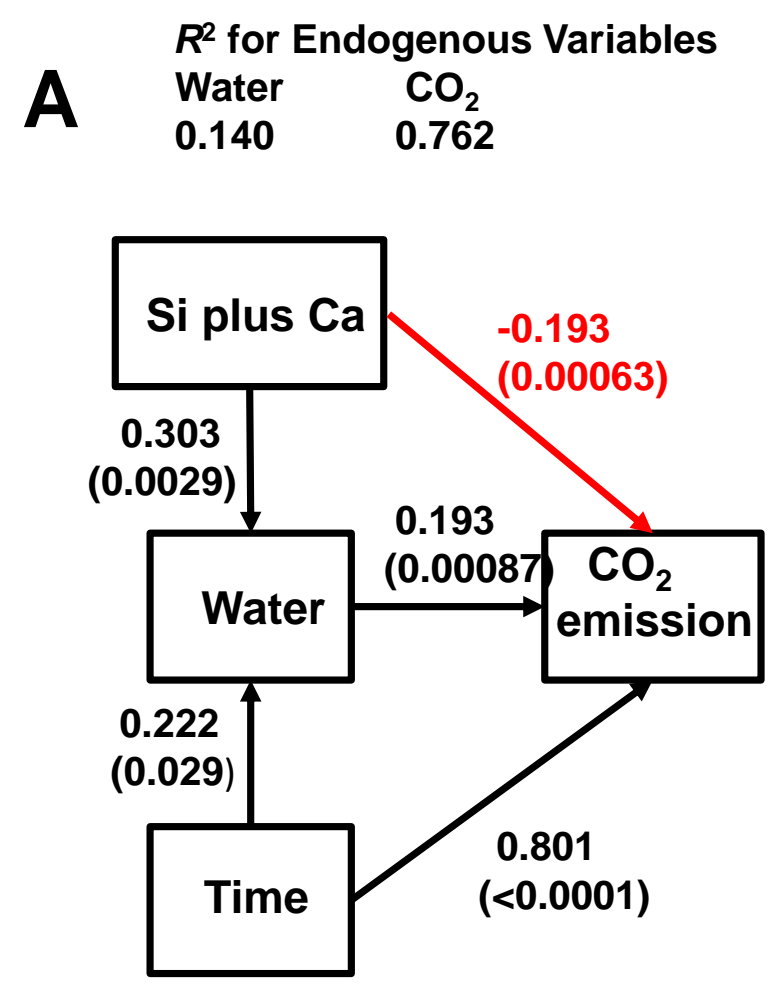

B $R^{2}$ for Endogenous Variables
0.140
0.357

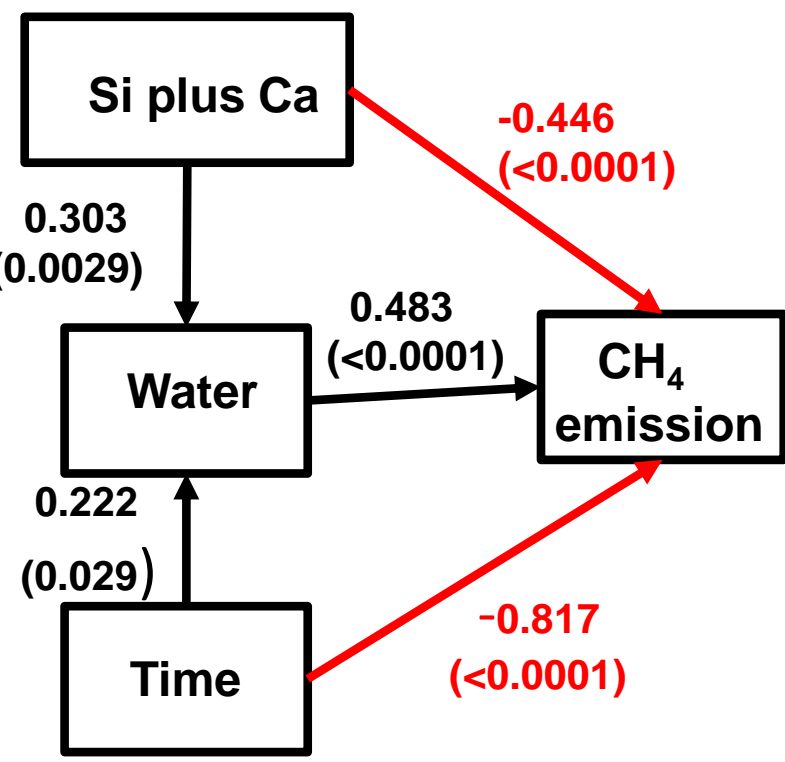

Figure S11. Diagrams of the structural equation models comparing plots amended with the silicate and calcium fertilizer versus the control plots that best explained the maximum variance of the soil $\mathrm{CO}_{2}(\mathrm{~A})$ and $\mathrm{CH}_{4}(\mathrm{~B})$ emissions and implying indirect effects from the effects of the amendment on the soil variables. Black and red arrows indicate positive and negative relationships, respectively. 

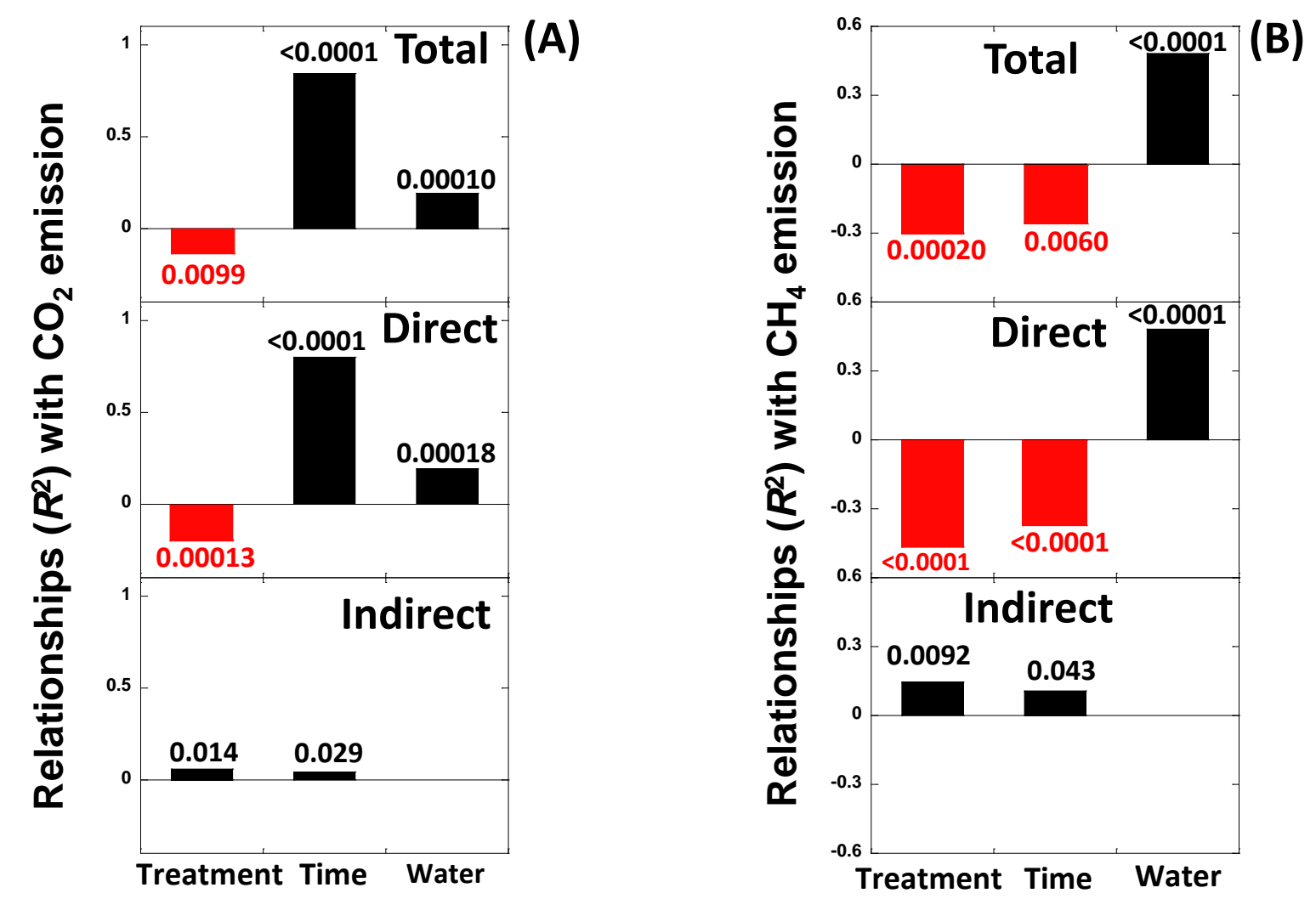

Figure S12. Total, direct and indirect effects of exogenous variables (soil variables) of the SEM models comparing plots amended with the silicate and calcium fertilizer versus the control plots that best explained the maximum variance of the soil $\mathrm{CO}_{2}(\mathrm{~A})$ and $\mathrm{CH}_{4}(\mathrm{~B})$ emissions. Black and red arrows indicate positive and negative relationships, respectively. 

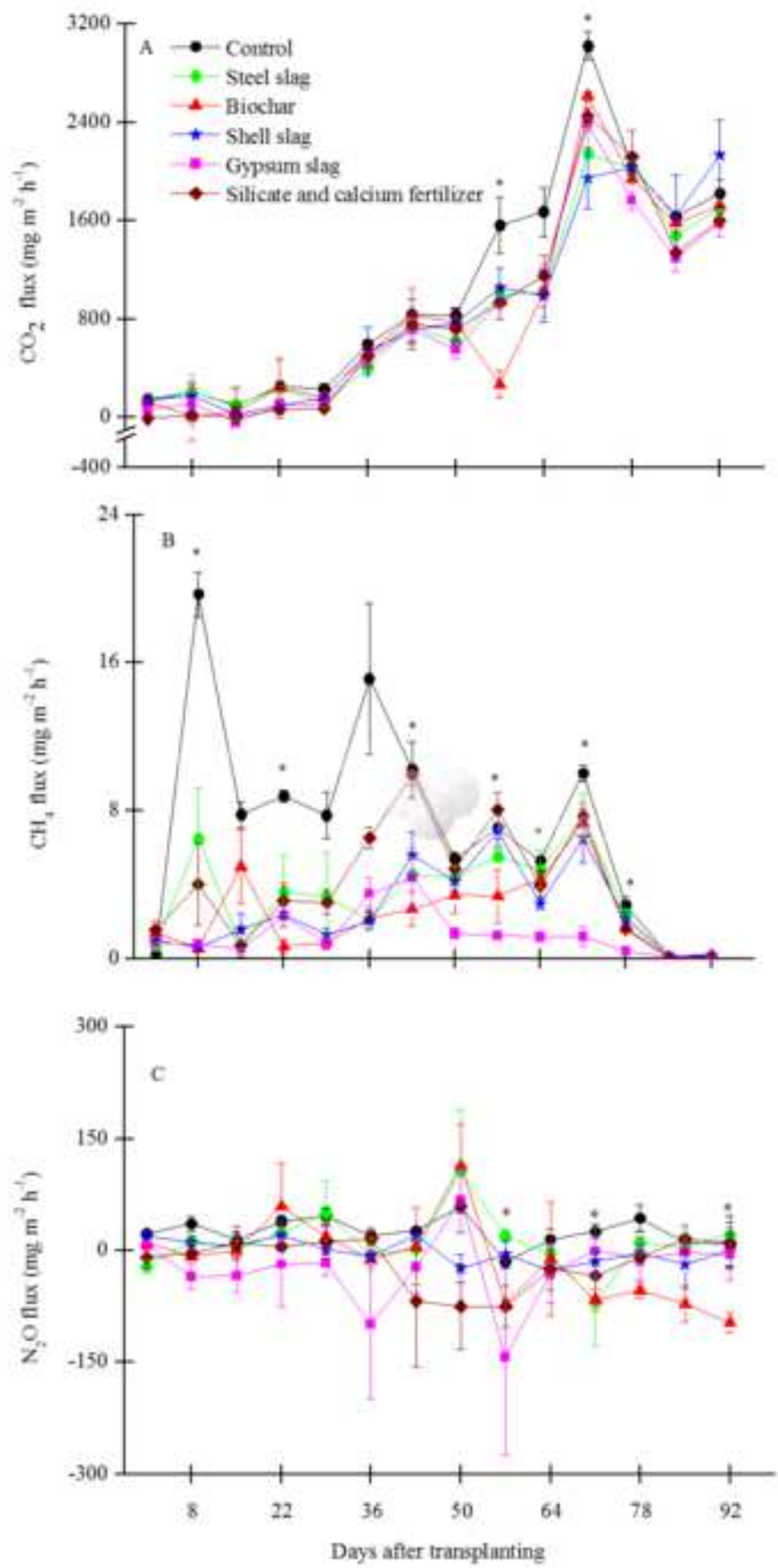

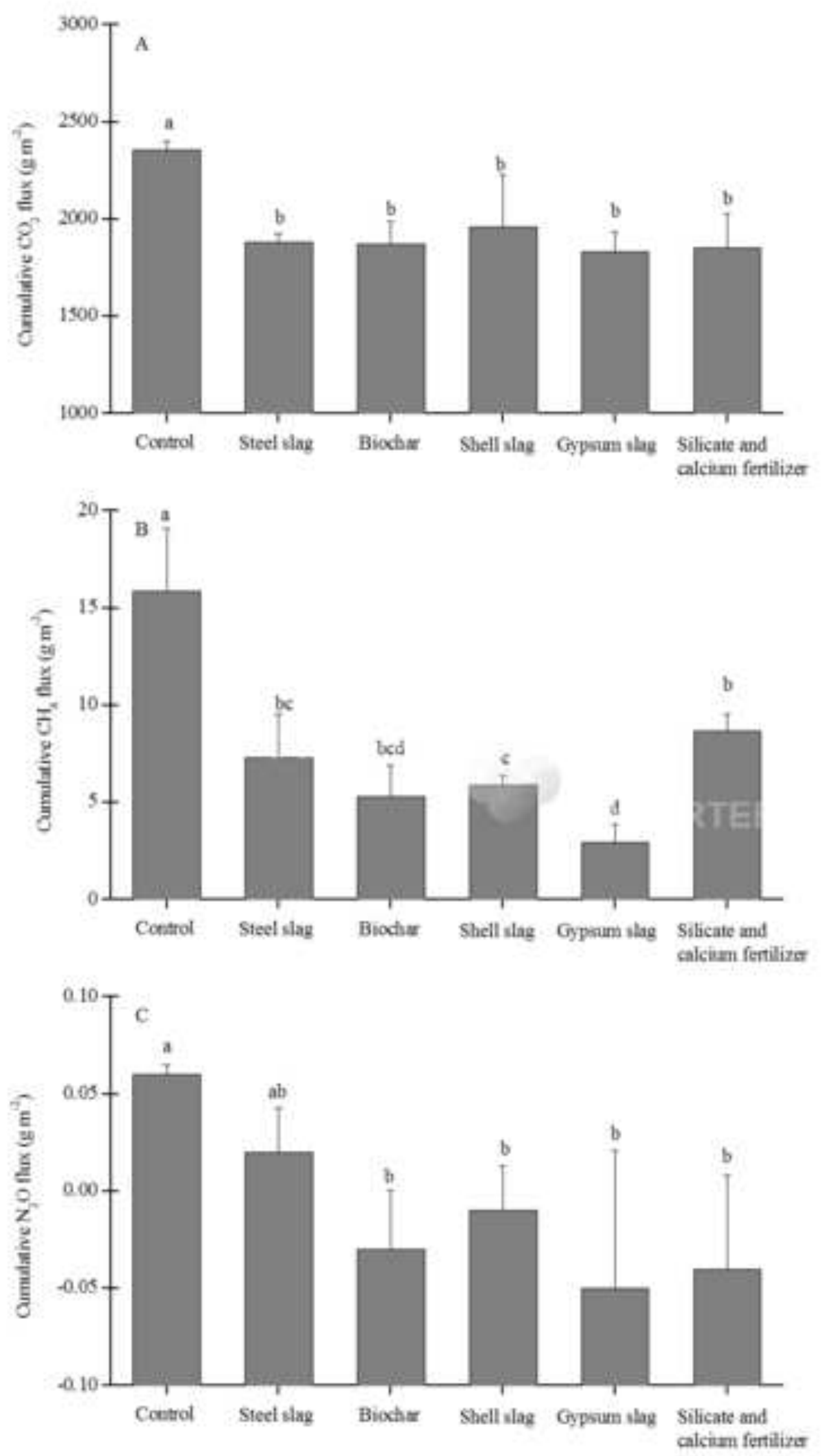

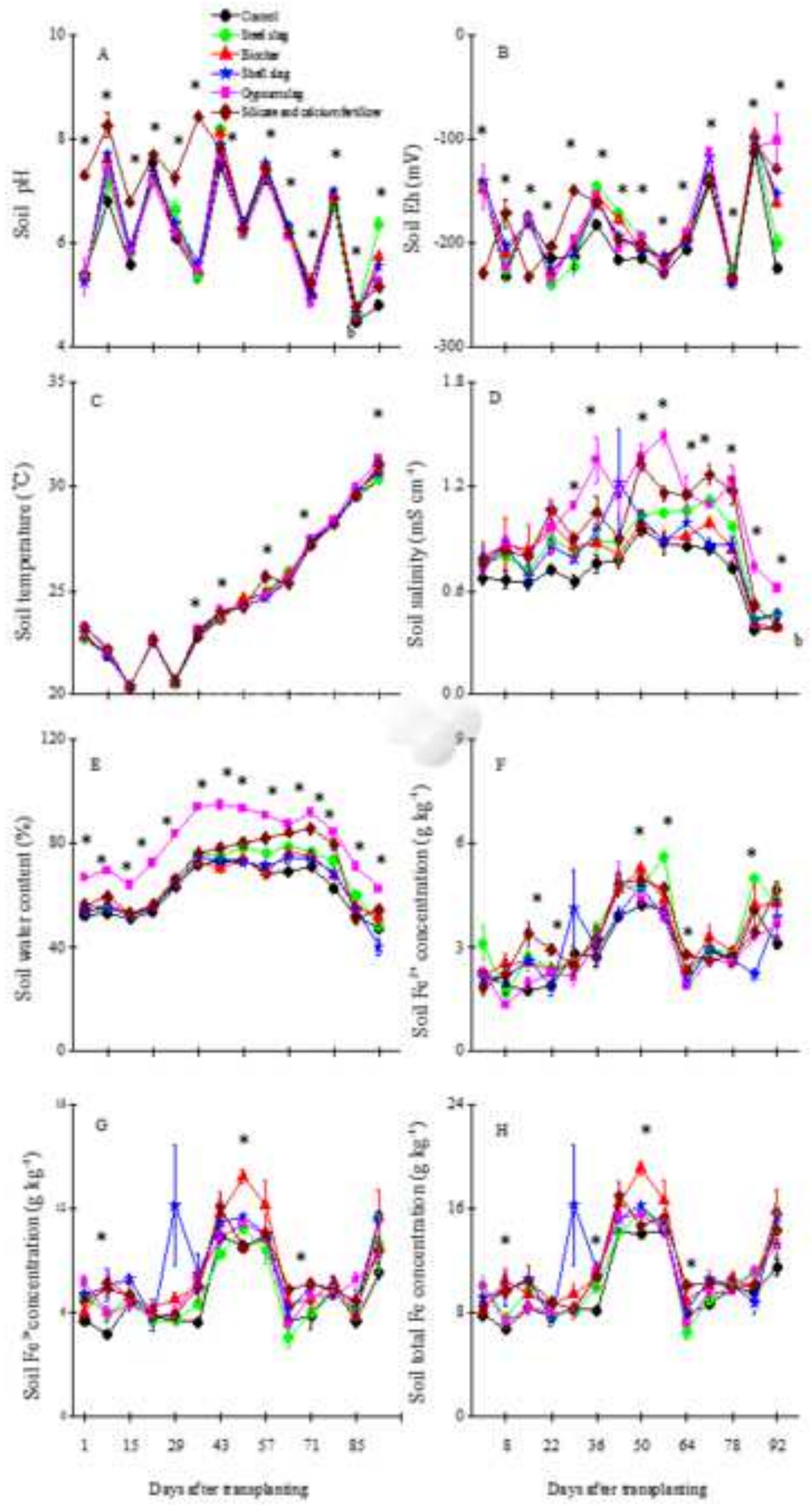

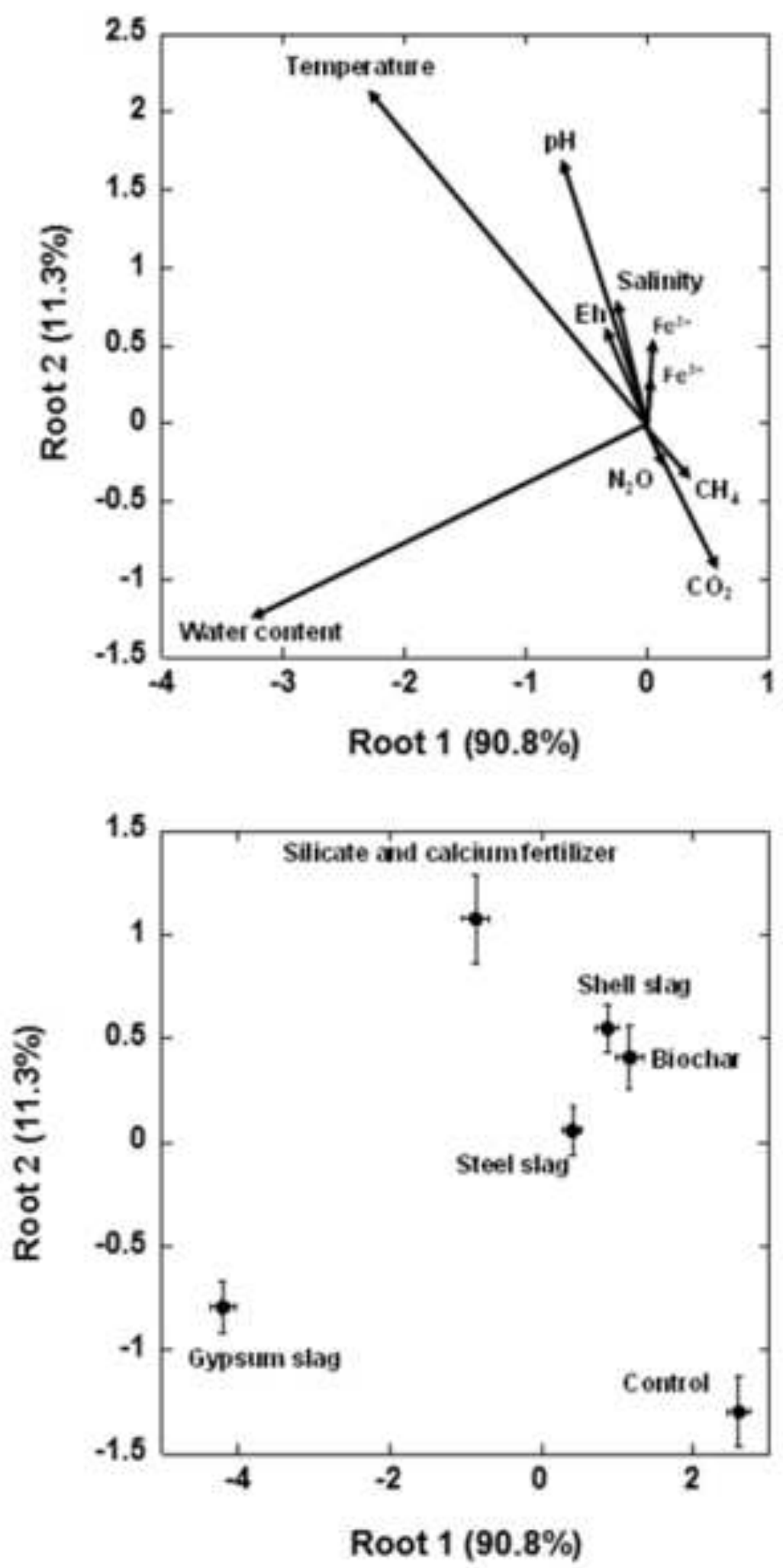


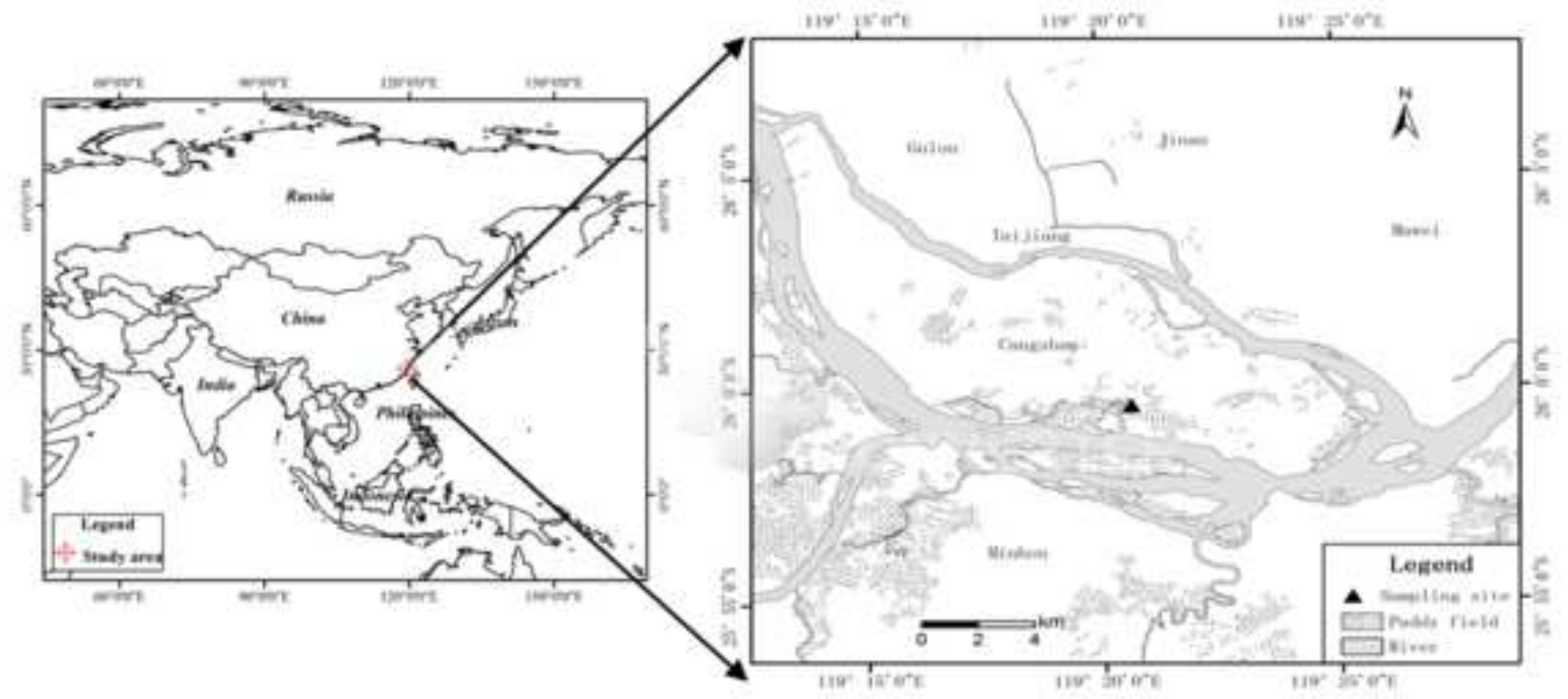



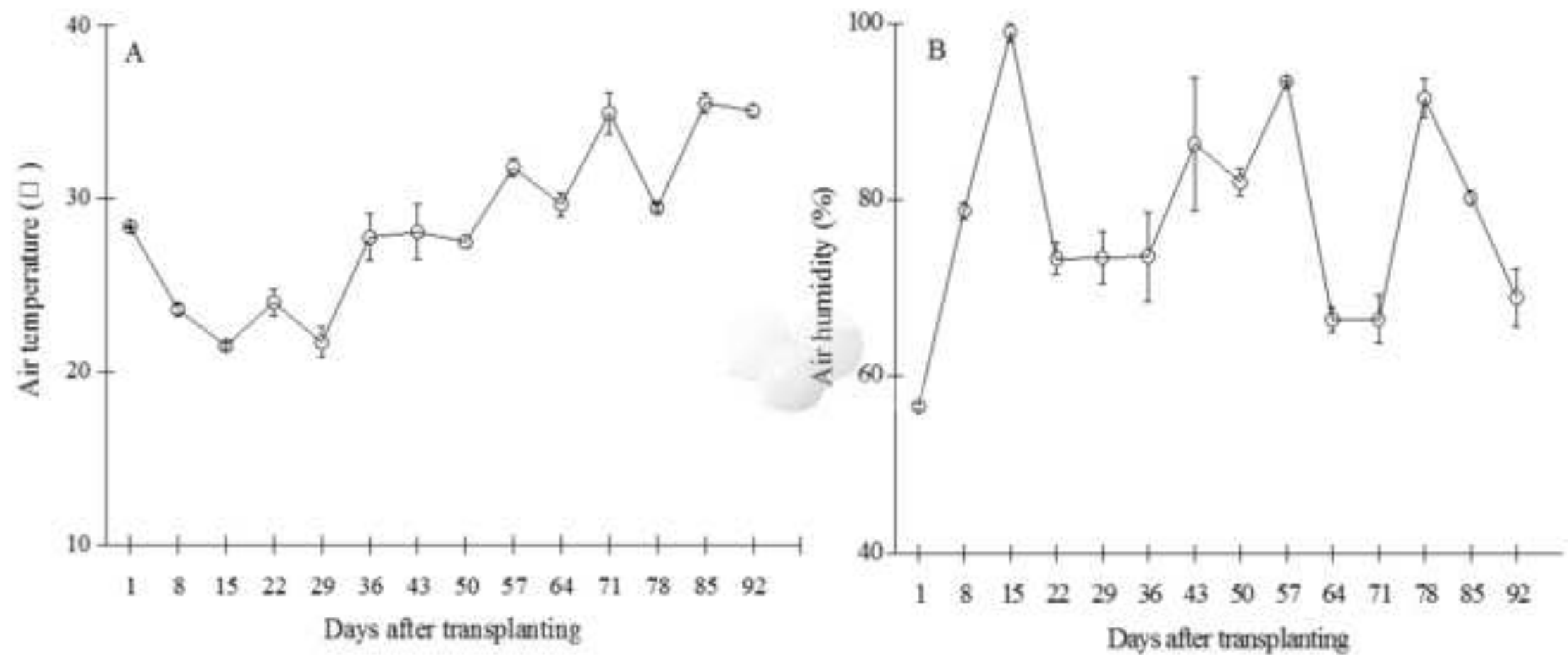


\section{$R^{2}$ for Endogenous Variables}

A Temperature $\quad \mathrm{Fe}^{2+} \quad \mathrm{CO}_{2}$
0.849
0.251
0.757

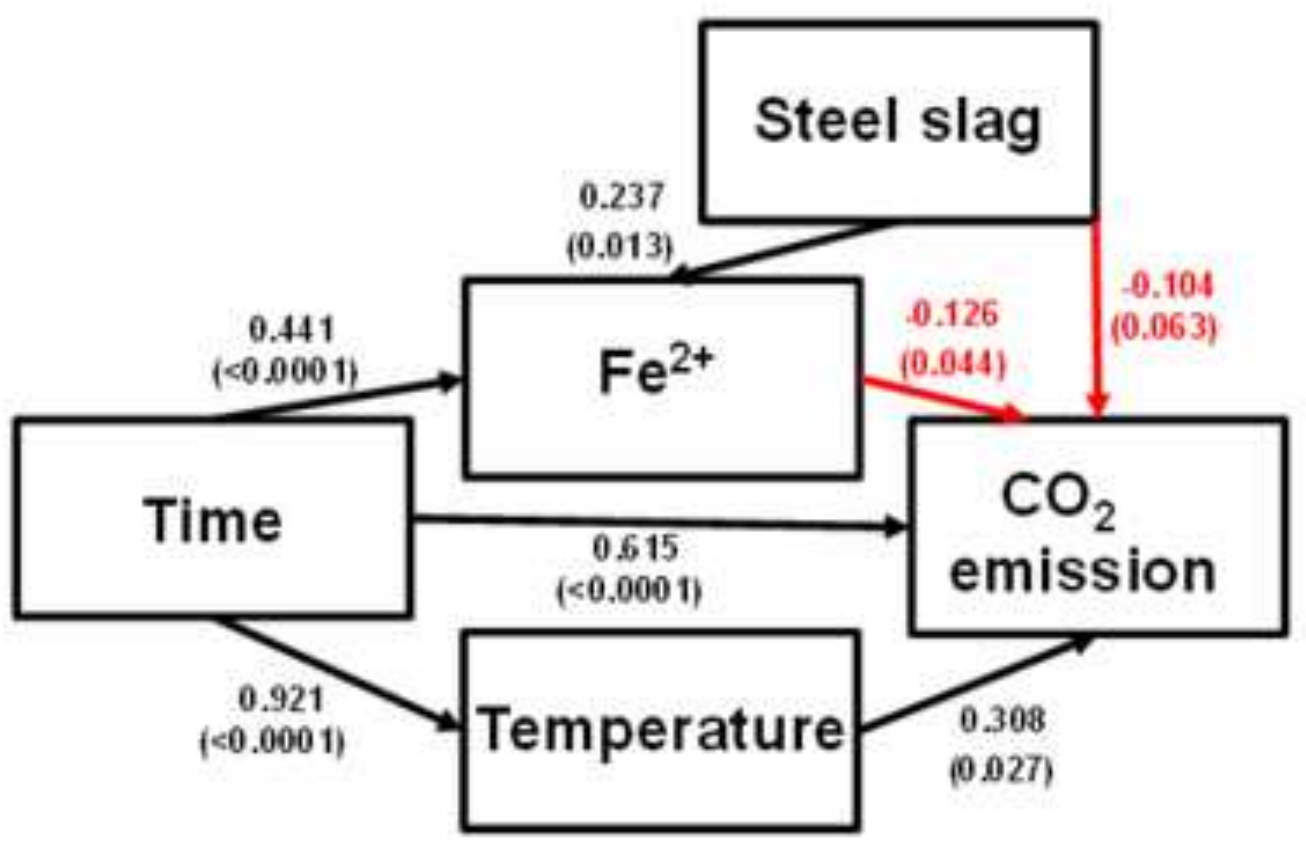

B $\quad R^{2}$ for Endogenous Variables Salinity Temperature $\mathrm{CH}_{4}$
0.136
0.849
0.355

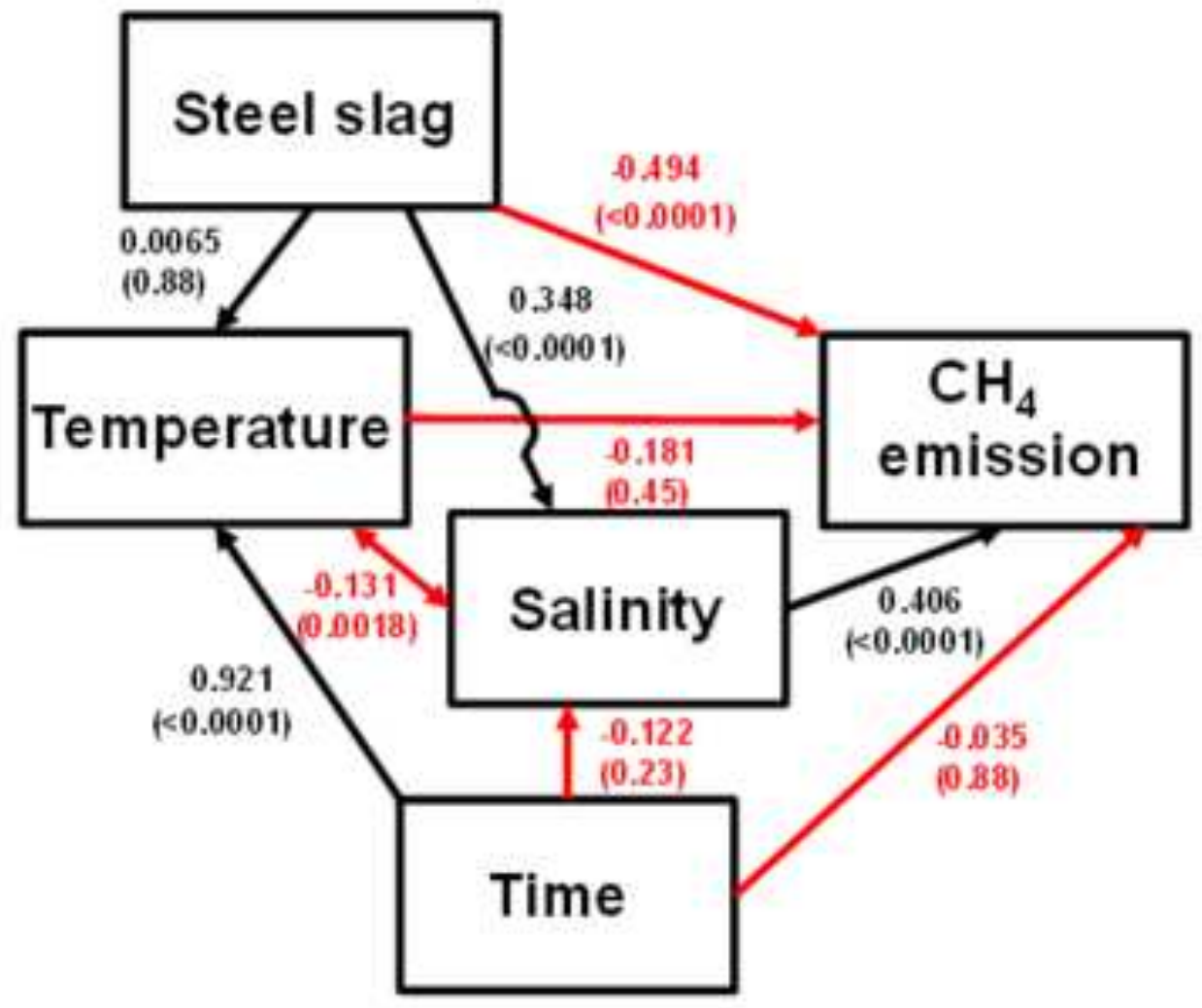



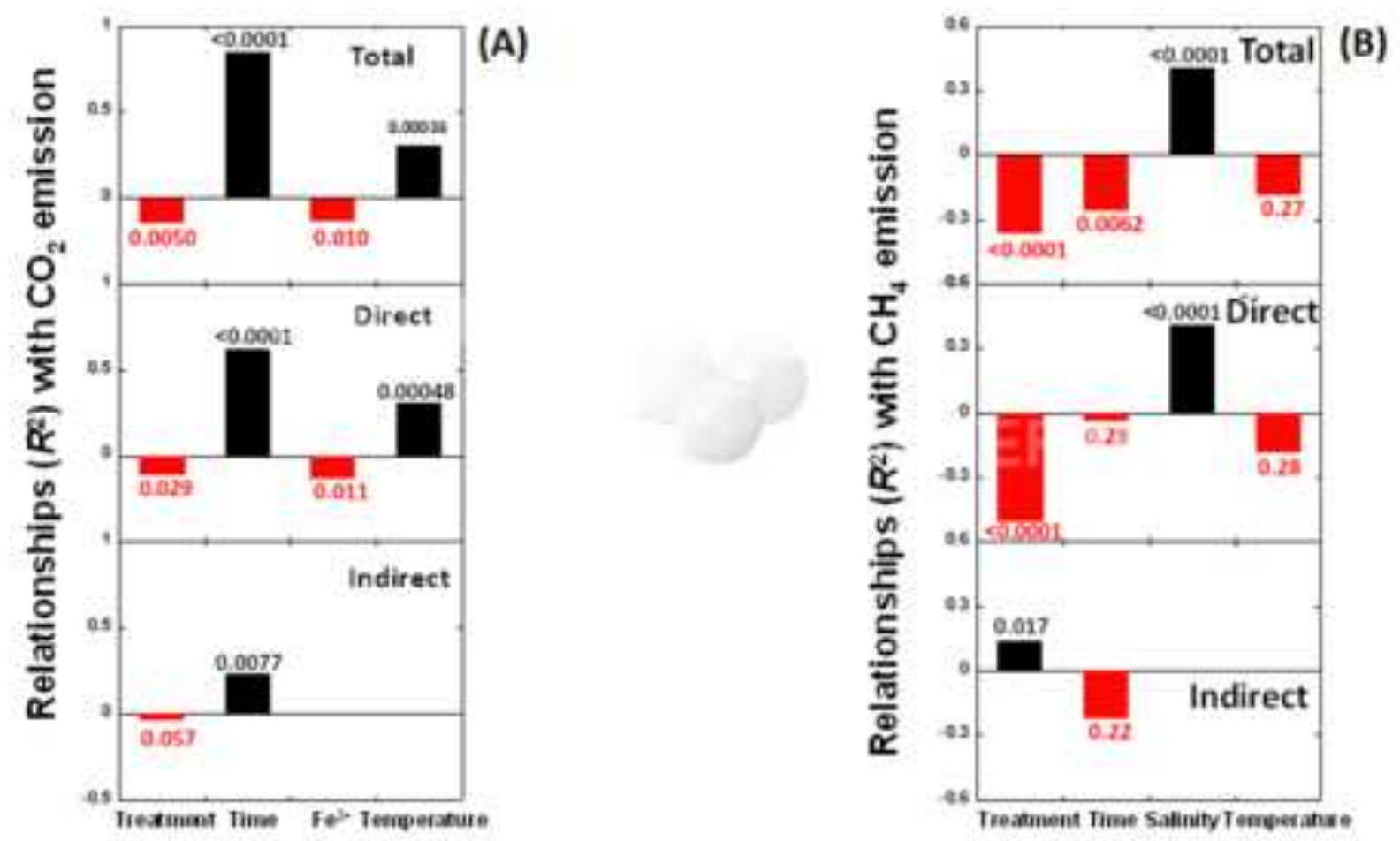
$R$ for Endogenous Variables

Temperature $\mathrm{CO}$.

$0.846 \quad 0.705$

(A)

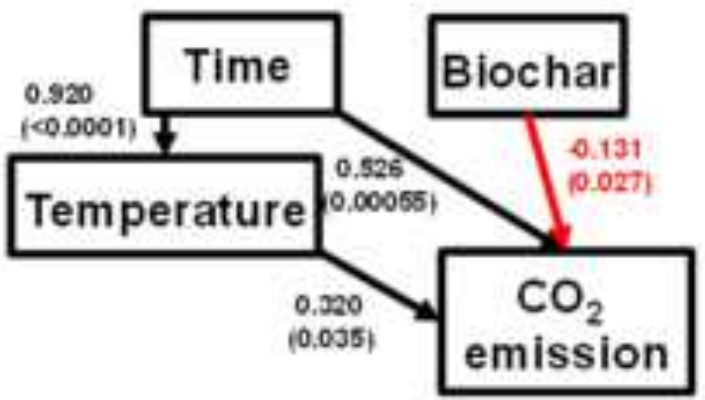

$R^{2}$ for Endogenous Variables Temperature Salinity $\mathrm{N}_{2} \mathrm{O}$

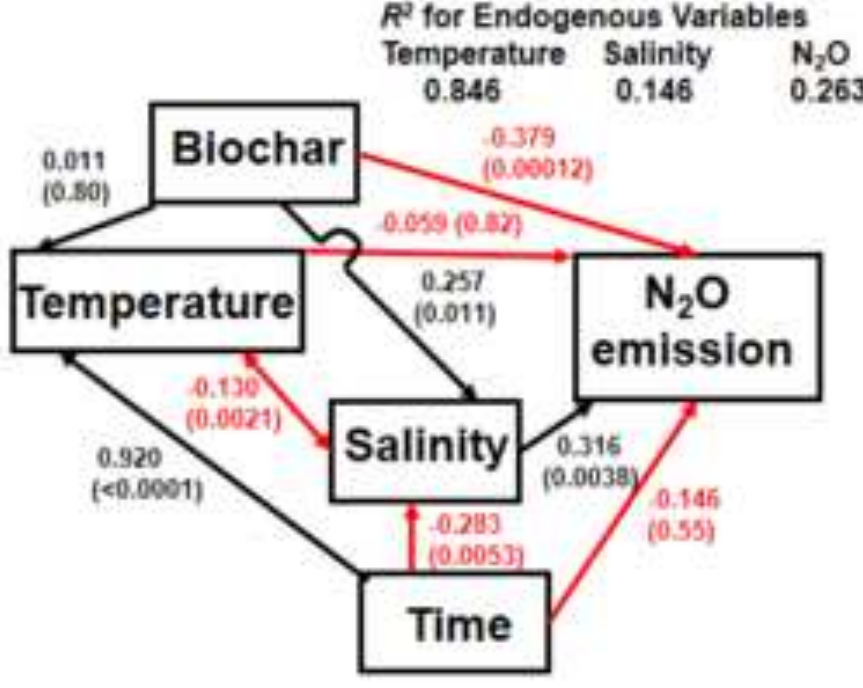

$R^{*}$ for Endogenous Variables

Water Salinity $\mathrm{CH}_{4}$

$\begin{array}{lll}0.059 & 0.146 & 0.350\end{array}$

(B)

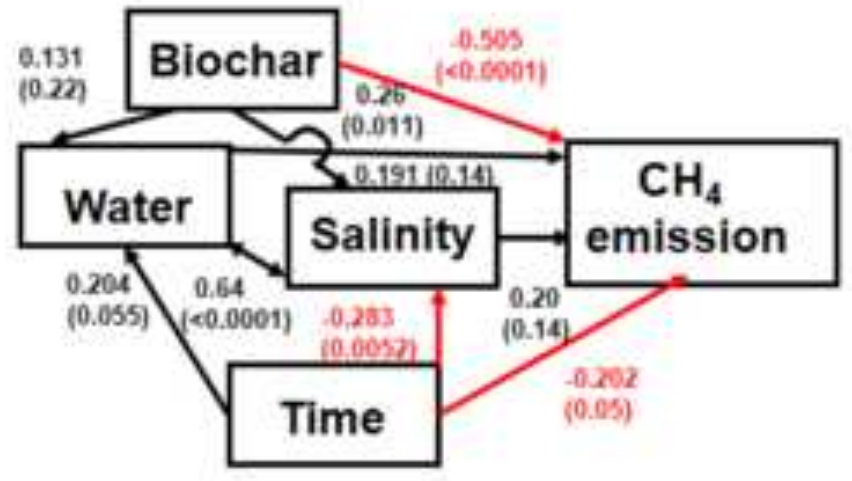

(c)

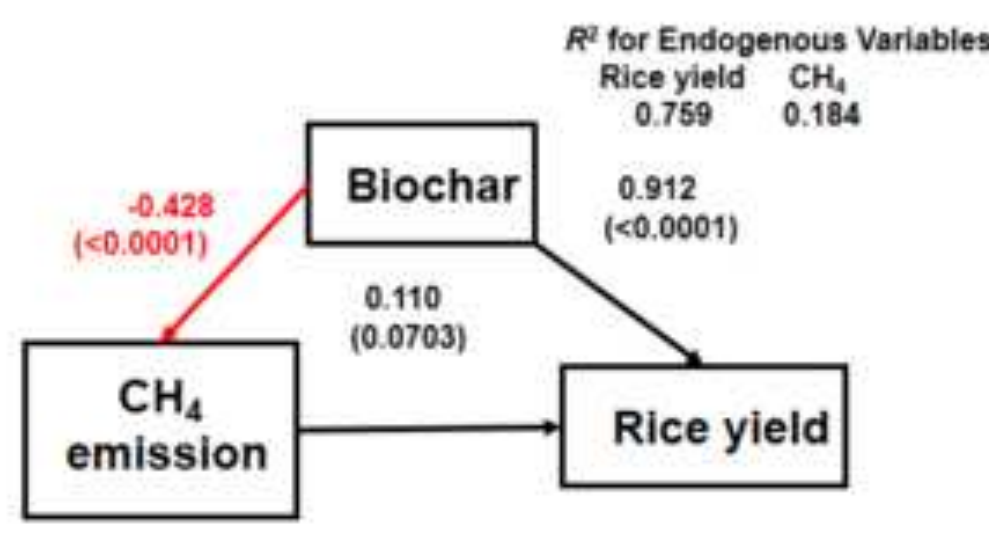



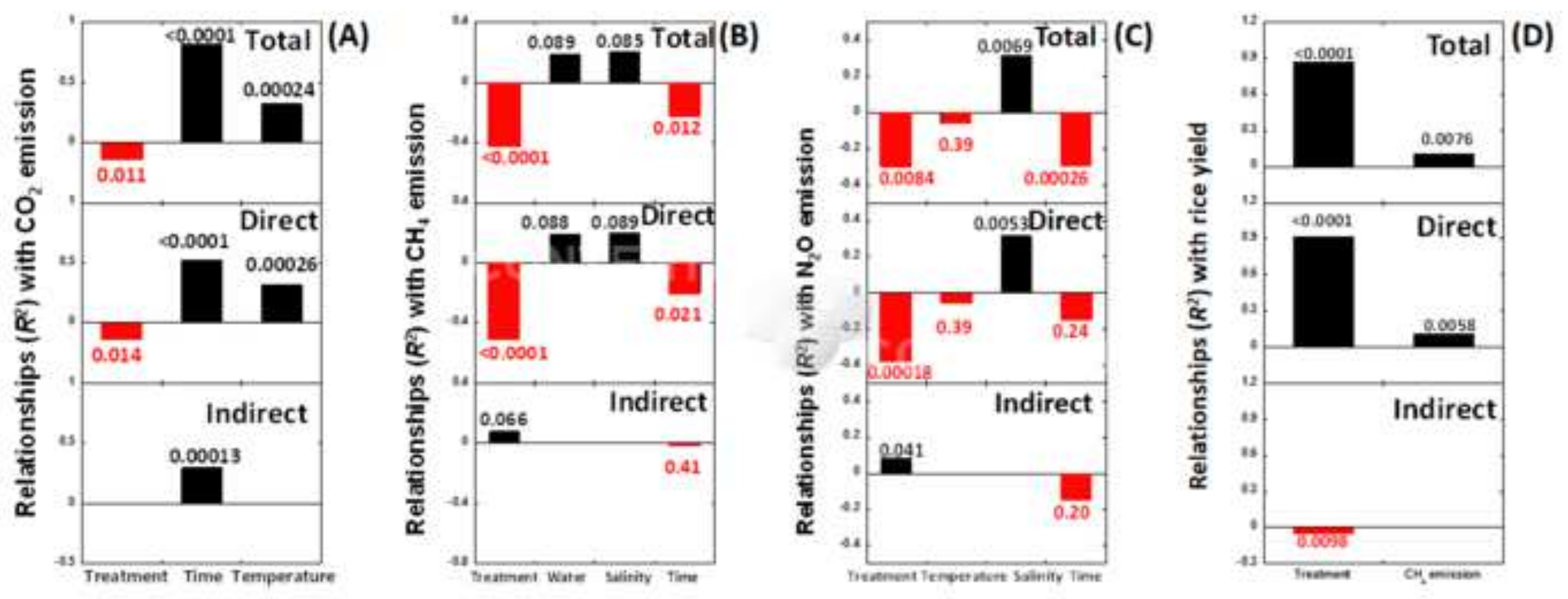


\section{$R^{2}$ for Endogenous Variables
Salinity $\mathrm{CH}_{4}$ \\ $R^{2}$ for Endogenous Variables
Salinity
$\begin{array}{cc}\mathrm{CH}_{4} \\ 0.146\end{array}$ \\ $\begin{array}{cc}0.146 & 0.333\end{array}$$$
\begin{array}{ll}
0.146 & 0.333
\end{array}
$$

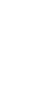

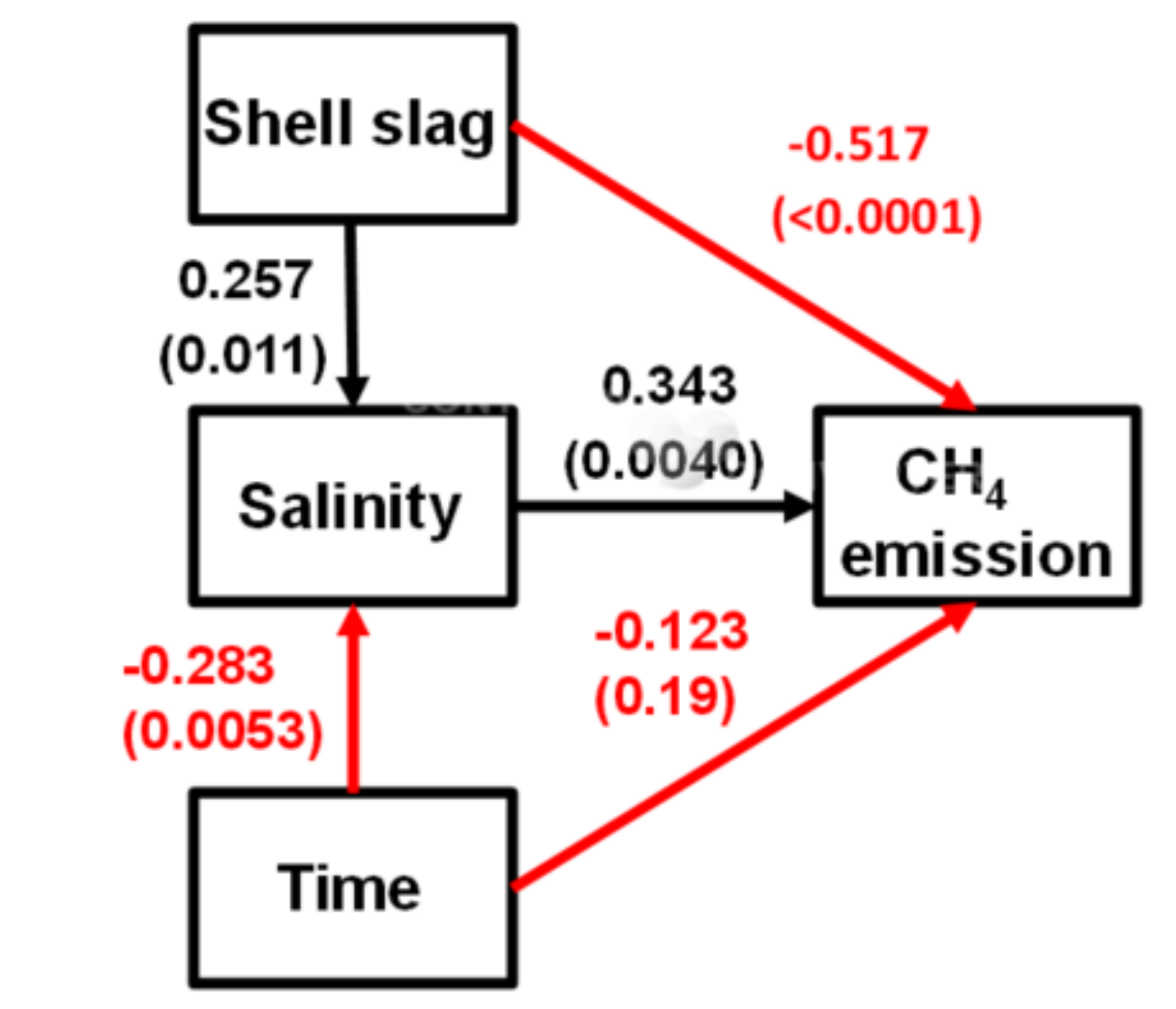

.

(1)

Figure

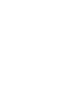




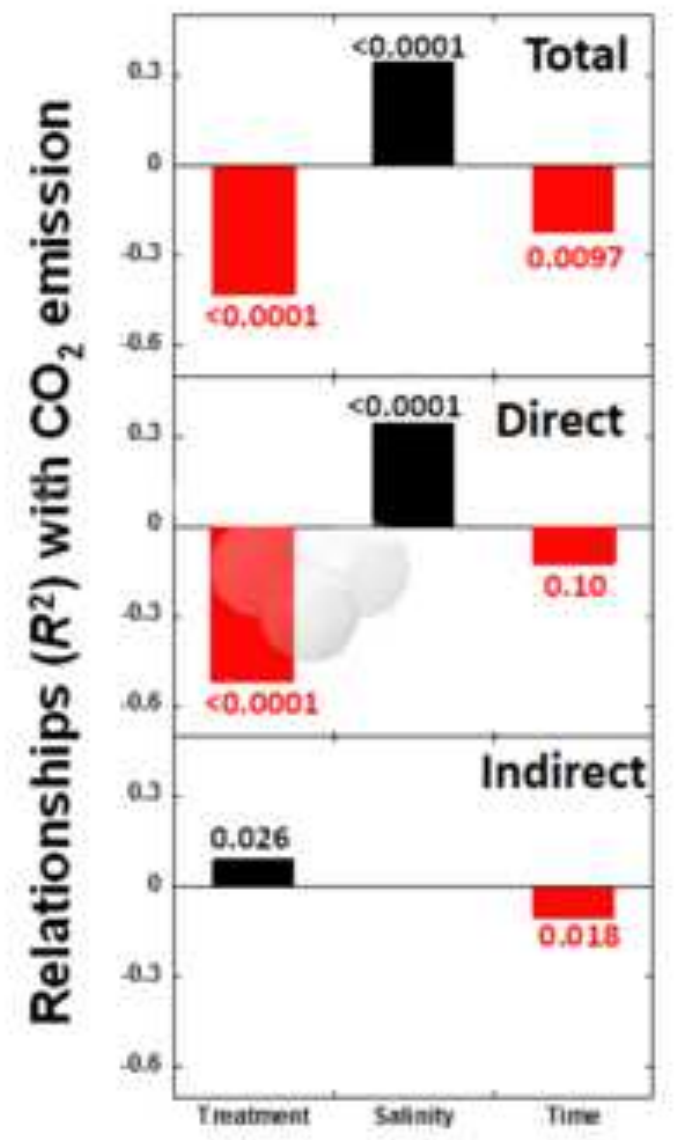




\section{A Water $\quad \mathrm{CO}_{2}$ \\ $\mathbf{0 . 4 5 5}$ \\ 0.743}

$R^{2}$ for Endogenous Variables

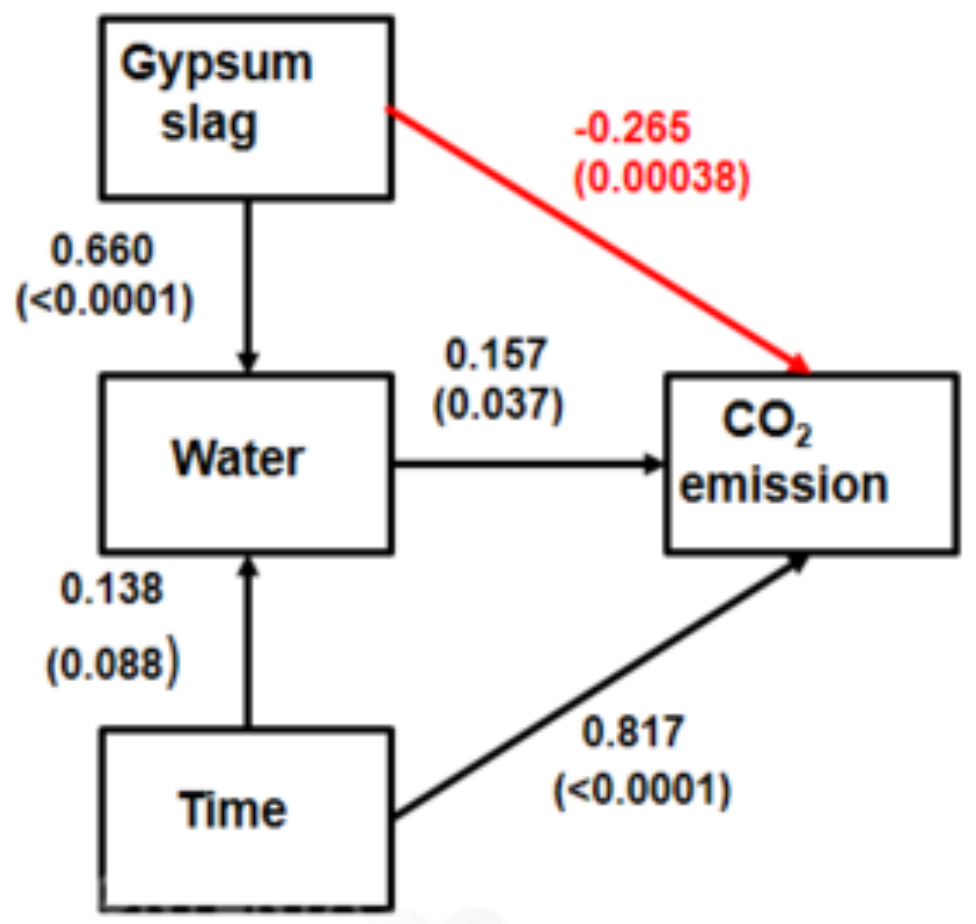

B $\boldsymbol{R}^{2}$ for Endogenous Variables Water

$\mathrm{CH}_{4}$

0.455

0.416

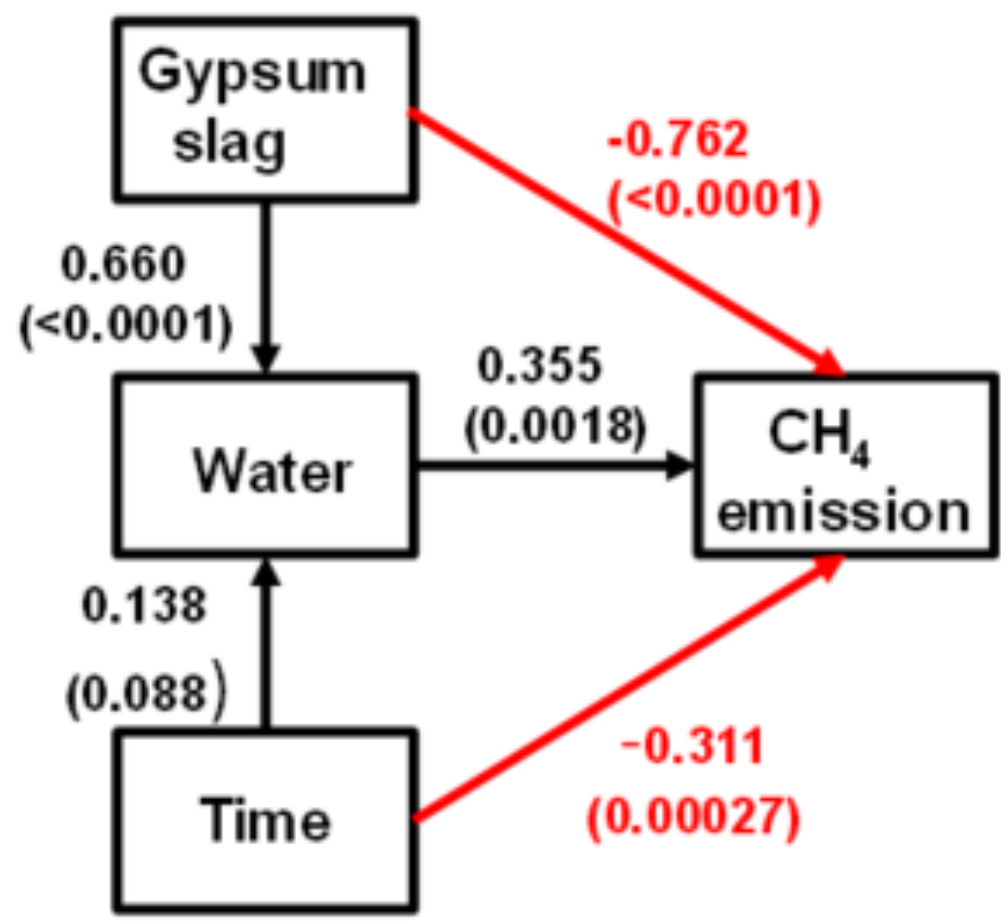



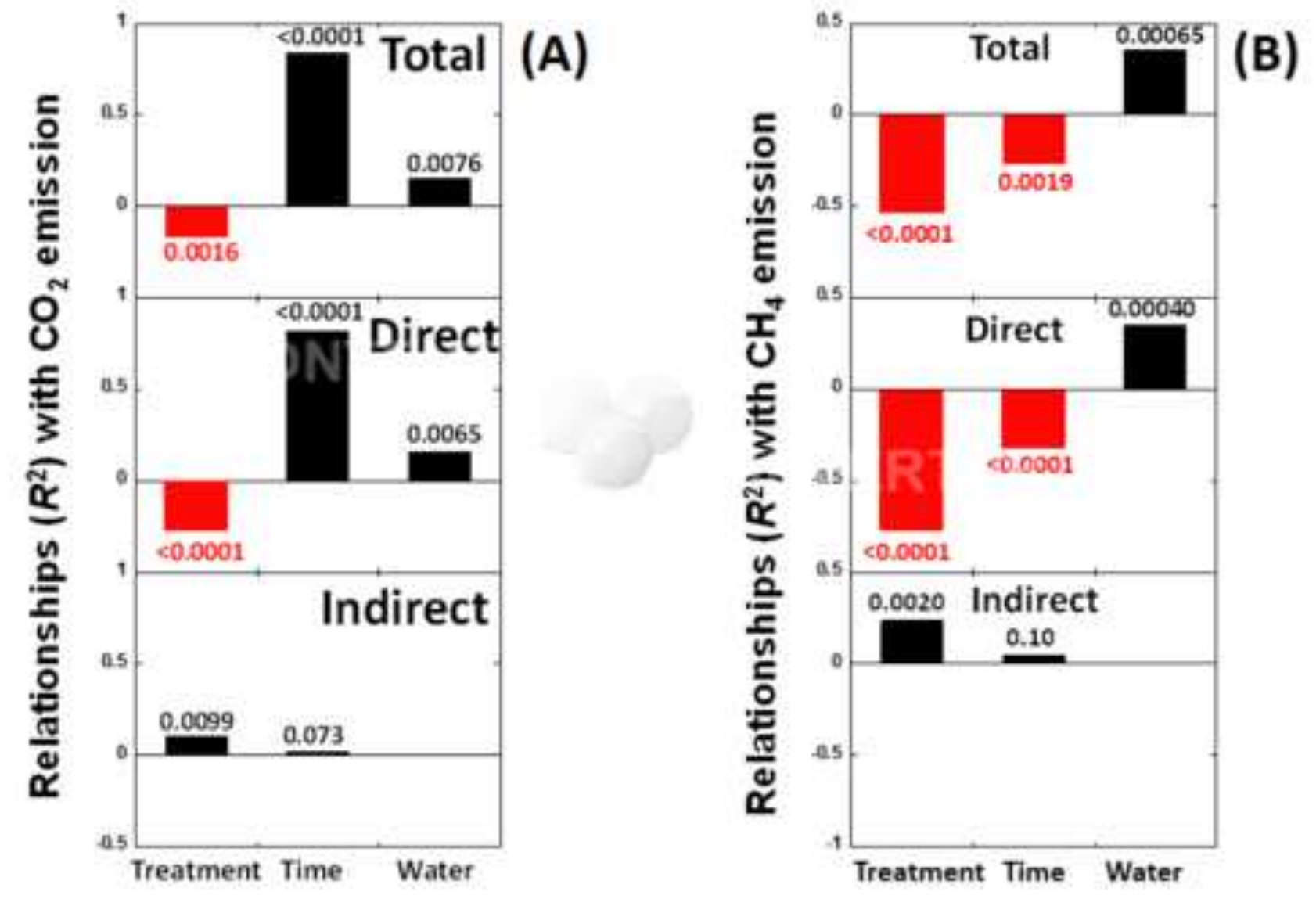
$\boldsymbol{R}^{2}$ for Endogenous Variables

A $\quad \begin{array}{ll}\text { Water } & \mathrm{CO}_{2} \\ 0.140 & 0.762\end{array}$

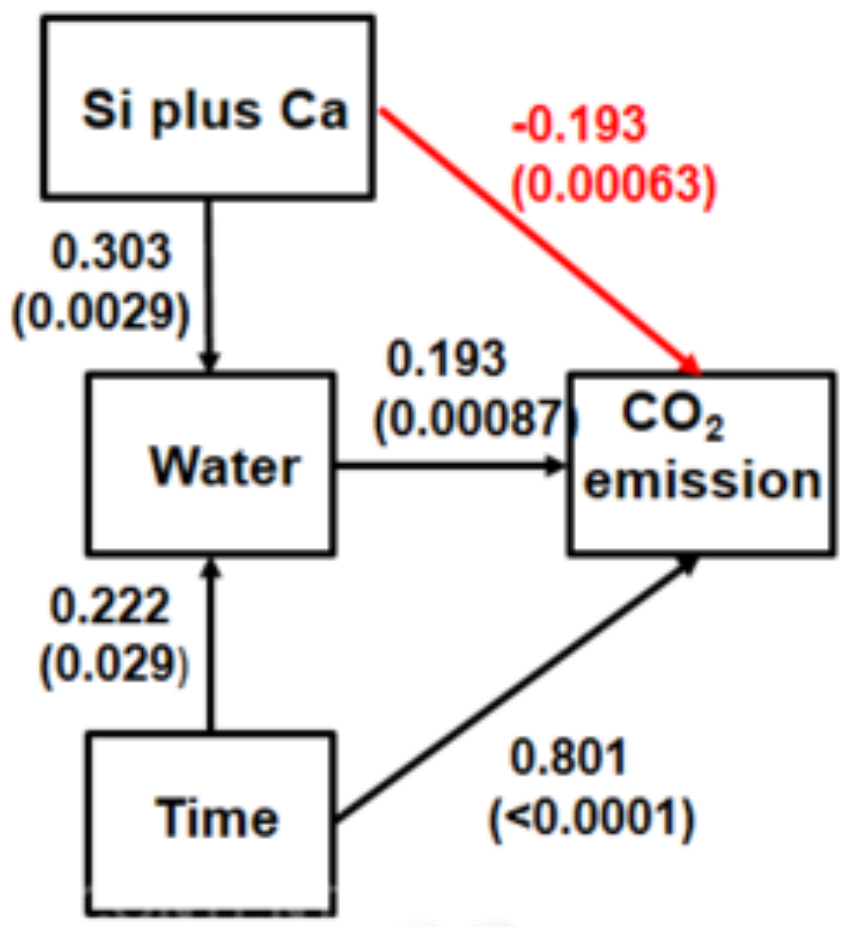

B $R^{2}$ for Endogenous Variables

$0.140 \quad 0.357$

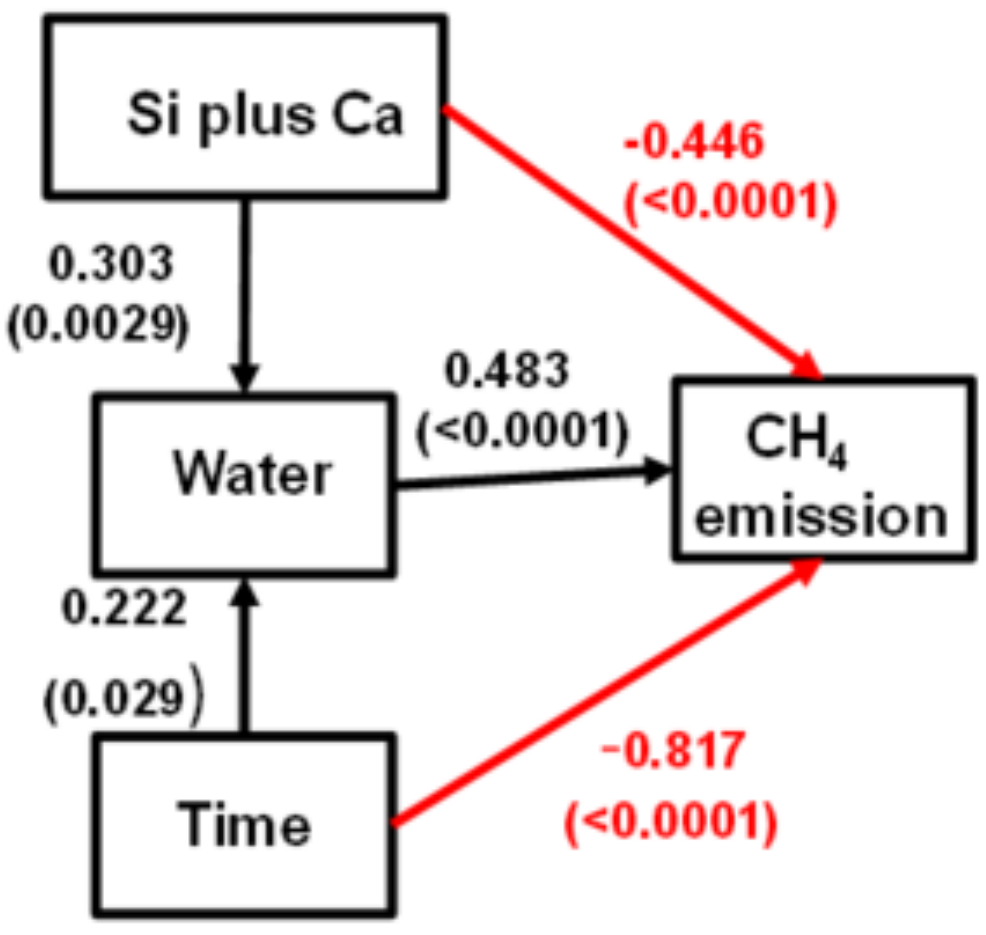



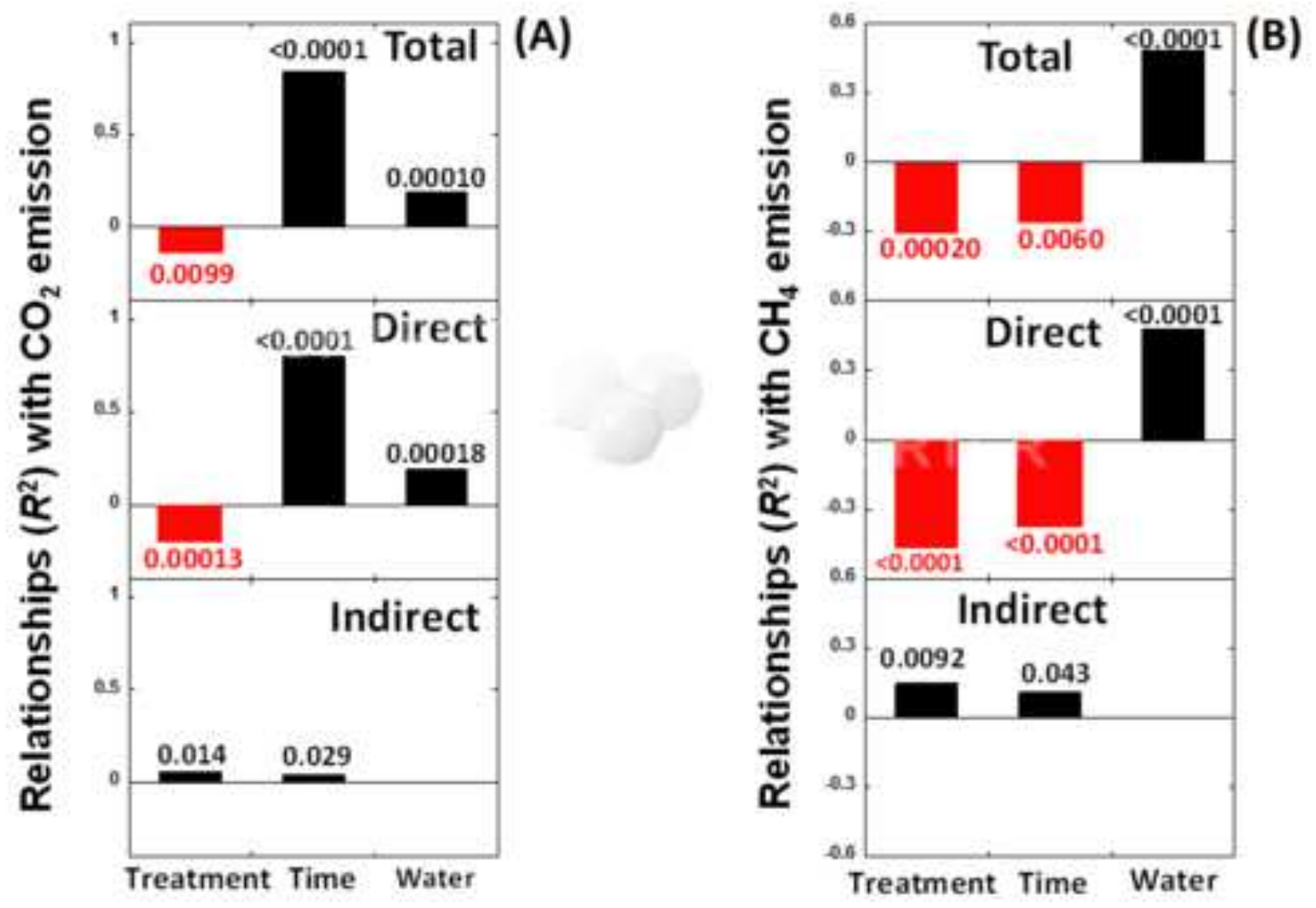